\title{
Implementation of forest stewardship plans: Understanding the extent of forestry practices applied on enrolled properties in West Virginia
}

\author{
Elizabeth K. Tichner \\ West Virginia University
}

Follow this and additional works at: https://researchrepository.wvu.edu/etd

\section{Recommended Citation}

Tichner, Elizabeth K., "Implementation of forest stewardship plans: Understanding the extent of forestry practices applied on enrolled properties in West Virginia" (2009). Graduate Theses, Dissertations, and Problem Reports. 2909.

https://researchrepository.wvu.edu/etd/2909

This Thesis is protected by copyright and/or related rights. It has been brought to you by the The Research Repository @WVU with permission from the rights-holder(s). You are free to use this Thesis in any way that is permitted by the copyright and related rights legislation that applies to your use. For other uses you must obtain permission from the rights-holder(s) directly, unless additional rights are indicated by a Creative Commons license in the record and/ or on the work itself. This Thesis has been accepted for inclusion in WVU Graduate Theses, Dissertations, and Problem Reports collection by an authorized administrator of The Research Repository @ WVU. For more information, please contact researchrepository@mail.wvu.edu. 


\title{
Implementation of Forest Stewardship plans: Understanding the extent of forestry practices applied on enrolled properties in West Virginia
}

\section{Elizabeth K Tichner}

Thesis submitted to the College of Agriculture, Forestry, and Consumer Sciences at West

Virginia University in partial fulfillment of the requirements for the degree of

\author{
Master of Science \\ In \\ Forest Resources Management \\ David McGill, Ph.D., Chair \\ William Grafton \\ Jennifer Steele, Ph.D.
}

Davis College of Agriculture, Forestry, and Consumer Sciences

Division of Forestry

Morgantown, West Virginia

2009

Keywords: Forest Stewardship Program, non-industrial private forests (NIPF), forest management, cost-share programs, multiple survey consistency 


\title{
ABSTRACT \\ Implementation of Forest Stewardship plans: Understanding the extent of forestry practices applied on enrolled properties in West Virginia
}

\author{
Elizabeth K Tichner
}

The purpose of this study was to understand the extent of forest management that is occurring on private forestlands enrolled in the West Virginia Forest Stewardship Program. To quantify the amount of forest management being applied, 295 telephone interviews were conducted in the Fall of 2005 inquiring participants about ten common forest management practices and extent of their implementation, in terms of acreage or mileage. In addition, this study sought to understand the factors associated with the number of respondents that had implemented practices as well as the amount of forestland on which these practices were applied, including practice recommendation, landownership objectives, and the use of cost-share programs. Sixty-five percent of the telephone survey respondents had participated in an earlier assessment of the state's FSP (Jennings, 2003). By linking the databases from these two studies, inconsistencies in responses pertaining to management practice implementation were examined. 


\section{Acknowledgements}

First and foremost, I would like to thank God for providing me an opportunity to continue my education and instilling the desire in me to work in and understand the world He has created for us. Without him and the people He has placed in my life, I would not be able to accomplish anything. I would like to thank my son, Isaac, for his encouragement and patience over the past few years. I hope our future will be filled with more time for fun, silliness, and countless memories. To my momma, my brothers, and the rest of my family-thank you for being there anytime I needed you and always reminding me that I could make it. I thank my dad who taught me the value of hard work and perseverance. I have been truly blessed to have been raised in the mountains of West Virginia, surrounded rivers and forests.

I would like to extent my sincerest appreciation to West Virginia University, the Davis College, and the faculty and staff of the WVU Division of Forestry and Natural Resources. Throughout my undergraduate education in Recreation, Parks, and Tourism Resources and my graduate education in Forest Resources Management, I have realized that the students of our Division are blessed with a group of caring, concerned, and dedicated professionals.

This project would not have been completed without the help of my committee members and others involved over the course of this project. The West Virginia Division of Forestry deserves special thanks for their financial and logistical support for this research. I would like to thank former graduate student, Dheeraj Nelli, and the WVU Department of Sociology and Anthropology for their efforts on this project prior to my involvement. I would like to express gratitude to Dr. Jennifer Steele for her extensive assistance and advice with data and my analysis, as well as her commitment to the project from start to finish. To William Grafton, I thank you

for your expertise in the Forest Stewardship Program, recommendations, editorial comments, and support. I extend my greatest appreciation to my committee chair and advisor, Dr. David McGill, for allowing me to take part in this research and supporting my research ideas. I am also grateful for his editorial guidance and expertise in research. 


\section{Table of Contents}

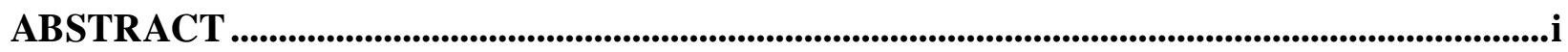

Acknowledgements ......................................................................................................................... iii

Table of Contents ......................................................................................................................................iv

List of Tables ...............................................................................................................................................

List of Figures................................................................................................................................................vii

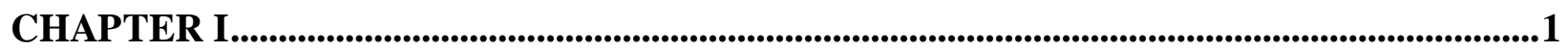

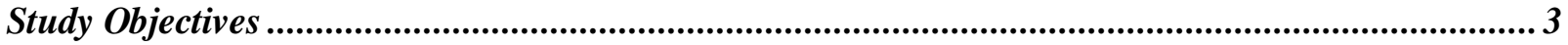

CHAPTER II .........................................................................................................................................5

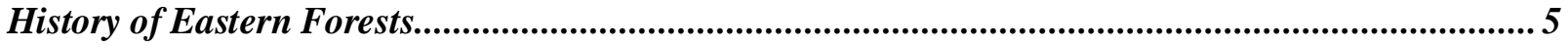

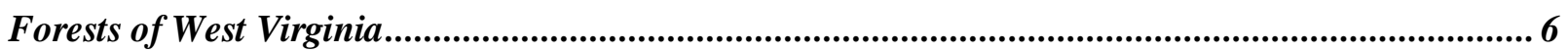

Characteristics and Trends Associated with NIPF Owners...............................................................9

Development of Programs and Policy to Assist NIPF Owners ........................................................... 11

Forest Stewardship Program and Related Cost-share Programs.................................................... 14

Evaluating the Forest Stewardship Program.................................................................................... 18

Evaluating the Reliability of Landowner Responses.................................................................... 21

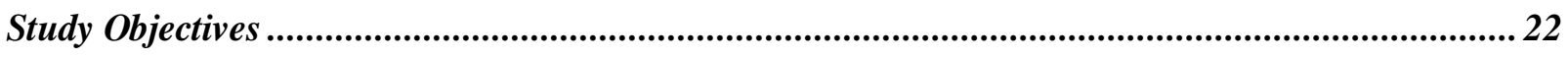

CHAPTER III ...................................................................................................................................................24

Survey Development and Sample Establishment ........................................................................ 24

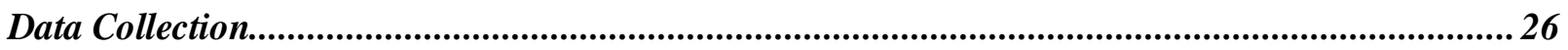

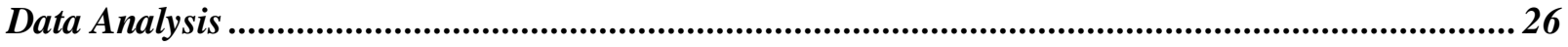

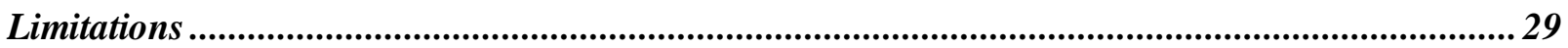

CHAPTER IV ..........................................................................................................................30

Response Rates and Participant Characteristics..................................................................................... 30

Overall Practice Recommendation ..................................................................................................... 31

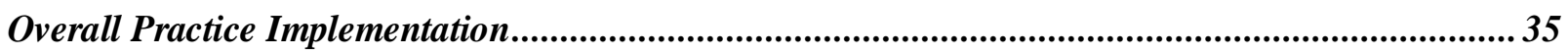

Land Ownership Objectives.................................................................................................. 44

The Use of Cost-share Programs.................................................................................................50

Consistency of Responses between Surveys...................................................................................5

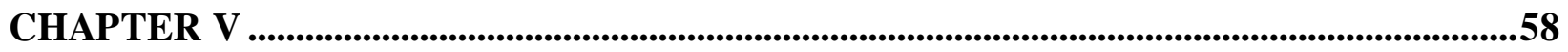

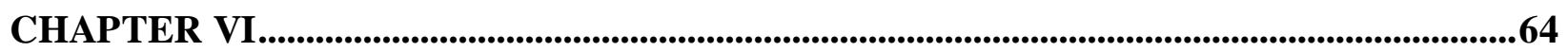

LITERATURE CITED .........................................................................................................................66

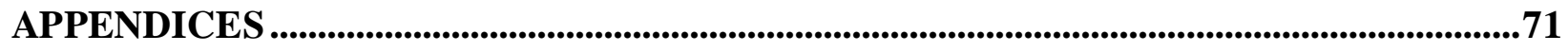

Appendix A: Definitions of Forest Management Practices ........................................................... 71

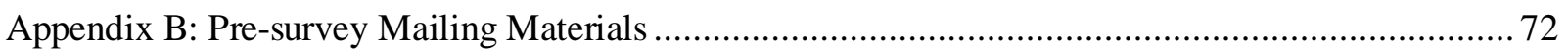

(1) Pre-survey Postcard ................................................................................................................. 72

(2) Pre-Survey Summary of Previous Study (Jennings, 2003)....................................................... 73

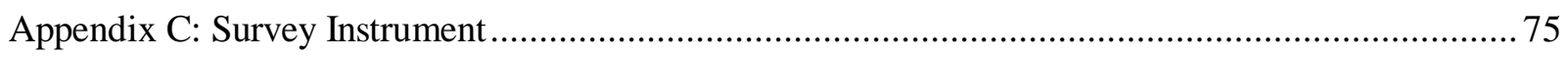




\section{List of Tables}

Table 1. Reasons for non-participation, based on pre-mailing postcard returns..........................25

Table 2. Consistency of response determination matrix..........................................................29

Table 3. Respondents who felt their stewardship plan was useful were asked about the frequency that they referred to their plan $(n=238)$......

Table 4. Respondents who did not feel their stewardship plan was useful were asked about the

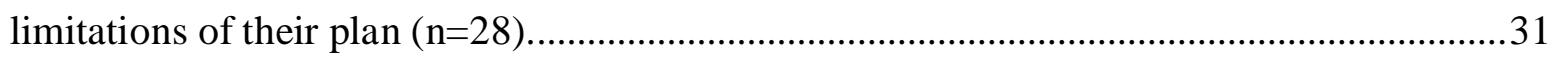

Table 5. Frequency of practices recommended in the respondents' Stewardship plan.................32

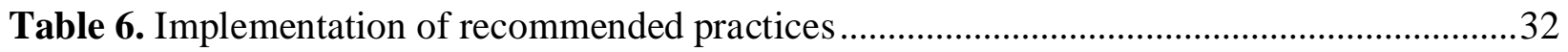

Table 7. Cross tabulation of the significant association between practice recommendation and

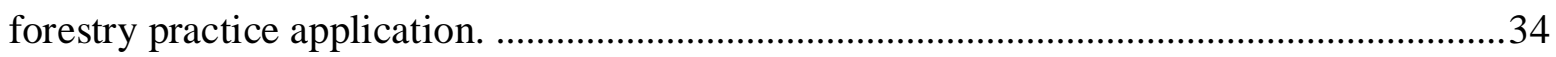

Table 8. Implementation of forest management practices........................................................35

Table 9. Pearson correlation coefficients between the extent of practice implementation. .........38

Table 10. Reasons for implementing forest management practices ..........................................39

Table 11. Reasons for failure to implement forest management practices..................................41

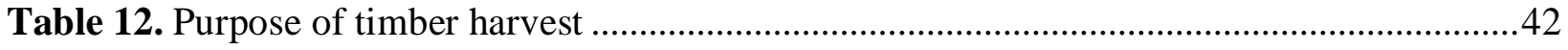

Table 13. Recreational opportunities that are possible or carried out. ........................................43

Table 14. Importance of Land Ownership Objectives ..........................................................44

Table 15. Responses on which land ownership objectives are 'Most' or 'Next most' important...45

Table 16. Recommended and applied practice (percent) by the objectives of most or next most importance among respondents ...................................................................................4 46

Table 17. Summary data and Analysis of Variance: Extent of practice implementation (natural log-transformed) by land ownership objectives ............................................................48

Table 18. Analysis of Variance: Extent of practice application by Objective Groups ................49

Table 19. Analysis of Variance: Bonferroni post hoc analysis of significantly different objective groups in terms of extent of practice implementation.

Table 20. Independent t-tests: Extent of practice implementation by the use of cost-share assistance programs

Table 21. Responses given by participants that reported practice application in the mail survey (Jennings, 2003) and had been recontacted through the follow-up telephone survey two years later. 
Table 22. Responses given by participants that reported practice no application in the mail survey (Jennings, 2003) and had been recontacted through the follow-up telephone survey two years later.

Table 23. Time of application for respondents that reported application in telephone survey, but not in the previous mail survey (Jennings, 2003). .57 


\section{List of Figures}

Figure 1. Time that has passed since the forest management practice was applied ....................40

Figure 2. Use of cost-share programs to implement timber stand improvement (TSI) ................50

Figure 3. Use of cost-share programs to implement grapevine control ....................................51

Figure 4. Use of cost-share program for tree planting .............................................................52

Figure 5. Use of cost-share programs for soil protection and erosion control ............................53 


\section{CHAPTER I}

\section{INTRODUCTION}

Of the 620 million acres of forests in the lower 48 states, nearly two-thirds are privately owned by industry, corporations, partnerships, tribes, families, and individuals (Butler \& Leatherberry, 2004). Family forest owners comprise 40 percent of these ownerships. In the eastern region of the United States, eighty-three percent of forestlands are under private ownership (Butler \& Leatherberry, 2004). The decisions that these landowners make in how they use and manage their forestlands can greatly impact the soils, water, biodiversity, wildlife, and timber markets. Ranking third in the nation in terms of percent forest cover, West Virginia's vast forest resources are vital to the sustainability of cultural, economic, and ecological resources within the state. The management of these forests plays a critical role in the long-term availability of timber resources, as well as other amenities that the forests provide to society, such as recreation, wildlife habitat, watershed protection, soil conservation, and carbon sequestration.

Over the past 50 years, research has shifted from evaluating these non-industrial private forestland (NIPF) owners in terms of their contributions to the timber industry and short-comings in forest management to understanding the objectives and goals of private ownership. Stoddard, Jr. (1942) and Barraclough \& Rettie (1950) were among the earliest studies that showed that private forestland owners are interested in owning land for purposes other than timber production. Because these owners were opposed to the types of harvesting they had witnessed on company lands, they had little interest in 'forest management' if it entailed liquidation of their woodlands (Barraclough \& Rettie, 1950). This led to the realization that forestland owners needed to be educated to understand the importance of proper care and management of their forestlands, regardless of their reasons for ownership. In the decades that followed, researchers began to understand the reasons for ownership and other characteristics that would influence their management action. In addition, there was a movement to develop policy and programs that assist landowners in achieving their management objectives (Stoddard, 1961; Keniston, 1962; Mills, 1975; Zivnuska, 1978). 
In the past, federal programs were created to assist non-industrial private forestland (NIPF) owners in managing their land by planting trees and preventing soil erosion. These programs were products of the heavy, destructive harvesting that occurred in the mid-1800s to the early 1900s, the Dust Bowl of the 1930s, and other misuses of the country's natural resources. By providing assistance to private landowners, the objectives of these programs were to restore the degraded forest and agricultural lands by planting trees and converting degraded or vacant croplands to forest.

There has been an increase in the number of NIPF owners holding smaller tracts of land (Birch, 1996; Butler \& Leatherberry, 2004). As forest holdings become smaller, the probability of management also decreases (Wear et al., 1999; Sampson, 2002; Butler \& Leatherberry, 2004). Other changes in this population are occurring as people escape from urban America to rural areas for recreation, second-homes, and a quieter life-style (Egan \& Luloff, 2000; Hailu, 2002; Rosenberger et al., 2002). This shifting population results in a community of landowners with more future focused goals and objectives including conservation of timber resources and investments to improve forested tracts for future generations (Egan \& Luloff, 2000; Butler \& Leatherberry, 2004). Because of this research, the importance of forest management on private lands, and changing societal needs (such as less dependence on timber products, higher demand for recreation, non-timber products), the federal government has broadened the scope of programs to assist NIPF owners. Creating programs that provide landowners with professional advice, financial assistance, and the 'know-how' to accomplish their ownership objectives and goals may be a more effective strategy to address the some problems associated with private forest management (i.e. costs, lack of resources, and knowledge).

With the passing of the Farm Bill of 1990, the Forest Stewardship Program (FSP) was created to provide technical assistance through a public or private certified natural resource manager to help private forestland owners develop stewardship plans for long-term forest management. The plan serves as a reference to apply practices that meet the goals and objectives they feel are important for forest ownership. Along with this technical assistance, participants are provided educational materials and are eligible for financial assistance through cost-share programs to aid in the implementation of forest management practices.

Illustrating the success of the program after the initial 10 years of administration, a national evaluation of the FSP found that $84 \%$ of respondents had begun to implement their 
stewardship plan (Esseks \& Moulton, 2000). State-level research has also indicated high implementation of recommended practices (Baughman \& Updegraff, 2002; Jennings \& McGill, 2005). Other research has indicated that the FSP participants are satisfied with the program and value of information and assistance that they obtain through the program (Esseks \& Moulton, 20001; Egan et al., 2001; Jennings \& McGill, 2005; Melfie et al., 1997).

There is much yet to be known about the effectiveness of the FSP. Multiple national studies of private forests have indicated that there is an increase in the number of ownerships, while the average size of holdings is decreasing (Birch, 1996; Butler, 2008). NIPF owners have changed their ownership objectives and have seen their forestland sizes change through time. Technical and financial assistance programs must also adapt to the needs and demands of this population. Additional evaluations are important in substantiating the continuation of the program, as well as federal funding. By examining the forest management activities that are occurring on FSP-enrolled forestlands, a better understanding of the program's effectiveness can be determined.

\section{Study Objectives}

\section{Background}

A previous study assessed the implementation of the recommended practices of Forest Stewardship Program throughout West Virginia ten years after its establishment (Jennings, 2003). FSP participants about were asked in mail surveys about ten commonly recommended practices, the implementation of such practices on their properties, and their involvement in other assistance programs. With at least 50 percent of respondents reporting some degree of practice application, these high implementation rates of recommended practices revealed the effectiveness of the program and advice given from stewardship consulting foresters. The ten practices surveyed were more often executed when participants also sought funds from other assistance programs. There were high levels of satisfaction with the program and the implemented practices among participants who had completed or started to complete some of the recommendations from their stewardship plans (Jennings, 2003).

While Jennings' (2003) assessment found that the majority of landowners were implementing practices recommended in their FSP plans, survey data can be fraught with unreliable responses that make inferences difficult or suspect. The reliability of landowner 
survey responses to questions dealing with forest ownership and forest management actions have been shown to have inconsistencies between survey methods. For example, a follow-up telephone survey of Pennsylvanian NIPF owners who had previously reported harvesting timber in a mail questionnaire indicated that 86 percent of the respondents confirmed the harvest; ten percent reported that they had never harvested on their property, and one respondent actually indicated that they did not own any forestland (Egan \& Jones, 1995).

Similar discrepancies were found in an assessment of the effectiveness of the Forest Stewardship Program in West Virginia (Egan et al., 2001). Only 88 percent of those initially reporting that they had harvested on their property confirmed this during the follow-up survey. This suggests that a more accurate understanding can be found by using multiple survey methods, whereas conclusions devised from single data collection methods can unreliable and erroneous (Egan \& Jones, 1995).

There may be various explanations for these discrepancies, but these studies illustrate that inconsistencies among responses for surveys can supply social researchers in the field of natural resources with inaccurate data and conclusions without on-site monitoring. Due to lack of resources (i.e. personnel and funding), it is unrealistic for public natural resource management agencies to employ extensive on-the-ground evaluations of government-assisted management on private lands. By using multiple survey methods, a greater understanding of the responses given from the same population can be found.

The first objective of this study is to provide clarity about the implementation that is occurring on NIPF lands enrolled in the Forest Stewardship Program by elaborating on findings from the mail survey conducted by Jennings (2003). This study seeks to understand the extent (acreage or mileage) of practice implementation. The second objective of this study is to validate the responses given by participants in the previous study of the West Virginia FSP (Jennings \& McGill, 2005) and to understand the inconsistencies that may occur when research is limited to one survey method. 


\section{CHAPTER II}

\section{LITERATURE REVIEW}

\section{History of Eastern Forests}

The land-use history of the eastern hardwood forests plays a major role in the development of the forests of today. During the early 1900's, innovative harvesting techniques and locomotive technology allowed timber companies to access rugged terrain and provide forest products for growing cities, while supplying the increasing population of the eastern United States with fuel for home heating, building materials, and other necessities (Clarkson, 1964). Intense fires frequently followed heavy harvesting (Clarkson, 1964; Alderman \& Mahoney, 2005). In some areas with deep organic soil horizons, these fires were hot enough to burn the top few feet of soil, thus limiting the site quality for many years due to the time required to rebuild the soil and upper horizon strata.

Timber was the backbone in the development of the United States, supplying materials for homes, fences, boats, fuel, bridges, and roads, in addition to everyday needs of early citizens of the country. As many people began moving west during the late $19^{\text {th }}$ century, forestlands were cleared for farming and pasturelands (Williams, 1989). As they approached the plains of the Midwest, many settlers chose to stay on the forest edge to access fuel, building materials, and other necessities that the forest provided them. Ranking among the top five in national manufacturing industries from 1850 to 1910 , timber was a large contributor to the nation's economy. After 1910, however, the timber industry dropped in importance as industry shifted to other manufacturing, such as shipbuilding, textiles, petroleum refining, and automobile production (Williams, 1989).

Commercial forest coverage has remained relatively constant since World War I (Clawson, 1979). Forest growth has exceeded consumption since the 1930s when the Great Depression led to less utilization of lumber for housing and development, and the introduction of electricity made the use of wood for fuel obsolete for most people across the country (Williams, 1989). Although there was an increase in the use of timber products for pulp and plywood from 1900 to 1980 , the amount of annual consumption was less than one-quarter of the total timber

products use of the early $19^{\text {th }}$ century (Clawson, 1979; Williams, 1989). Lower consumption 
rates, the conversion of farmland back to forests, the US Forest Service's campaign against forest fires, coupled with the initiation of management practices to stabilize the long-term timber supply have led to the increased commercial and non-commercial forestlands (Williams, 1989). The annual net growth of timber increased from 5 billion cubic feet in 1920 to nearly 22 billion cubic feet (Clawson, 1979).

Between the 1960s and 1970s, inventories of eastern forests indicated that the forests were rebounding from the exploitation that occurred at the turn of the century (Nyland, 1992). In 1970, commercial forest coverage was estimated at 500 million acres and non-commercial forests were estimated at 254 million acres (Clawson, 1979). Shifts in timber markets during the 1970s led to another episode of extensive harvesting, focusing on diameter-limit cuts of select species. On private lands, silviculture and proper forest management were not priorities as landowners sought to capture the financial benefit of high quality oaks, black cherry, yellow birch, and white ash (Nyland, 1992). In addition, harvests in West Virginia during 1993-94 were also driven by the high-value sawtimber (Fajvan et al., 1998). These economically focused practices reduced basal areas of highly marketable species such as oak and yellow-poplar (Fajvan et al., 1998). With little consideration for the future of forestlands, the resulting forests were inconsistently stocked stands with poor-quality stems comprised of less vigorous, less valuable, and genetically inferior residual trees (Nyland, 1992).

\section{Forests of West Virginia}

West Virginia ranks third among states in the United States in terms of percent forest cover. Of the 12.0 million acres of forests that cover 78 percent of the state, over 88 percent is owned by private groups and individuals (Griffith and Widmann, 2003). Because of the extensive private ownership of these lands and their resources, providing assistance and management advice to the private individuals owning these forestlands is essential to maintain the culture and economy of the state, as well as the environment and biodiversity of the state's forest resources.

The rural culture that has developed in the state of West Virginia is a product of the mountainous terrain, vast forests, ubiquitous rivers and streams, and the small communities that dot the landscape. The forests provide privacy, aesthetics, and recreation to residents and visitors. From an economic standpoint, these forests provide jobs to people who live in the 
isolated hollows and valleys throughout the state. The state's dependence upon natural resources, from coal extraction or timber production, has played a major role in the economy and culture that has developed. Childs (2005) conducted an economic analysis for the wood products industry and estimated the overall impact that these industries have on the state's economy, claiming:

"West Virginia's wood products industry contributes more than \$4 billion annually to the West Virginia economy. West Virginia's wood products industry accounts for nearly 30,000 jobs across the state and pays in excess of $\$ 703$ million of employee compensation. All of this activity generates significant tax revenues for the state, including $\$ 45.4$ million in timber severance taxes, consumer sales taxes, personal income taxes, corporate net income taxes, and business franchise taxes (p. 9, Childs, 2005)".

Another notable source of the state's income is generated from wildlife-associated recreation. These activities, including hunting, fishing, and wildlife watching, account for $\$ 803$ million in economic impact in West Virginia (Childs 2005). Sustainable management of the state's forest resources will allow for the future prosperity of these industries and the jobs they supply.

In regards to diversity, Hicks (p 187, 1998) described the wide range of environments that support the many vegetative species in the central Appalachian region:

“...due to factors such as aspect, slope position, geology, past land use practices, patchy forest fires, and past cutting practices, the forests of the central hardwood region actually consist of a complex mosaic of stands with a high degree of internal diversity."

The WV Division of Natural Resources reported that there are currently 146 vegetative communities recognized because of their existence in the state (WVDNR, 2003). The mixed mesophytic forests that exist in much of the plateaus and hills west of the Appalachians (including West Virginia) support one of the most biologically diverse temperate regions of the world. Throughout its range, 95 percent of this habitat has been converted or degraded over the past two hundred years. Under sustainable and conservation-minded management, the second- 
growth forests have the potential to recreate the immense range of biodiversity once represented (Ricketts et al, 1999).

\section{Forest Management Challenges}

Some management implications that occur on public forestland are not subject to the political boundaries drawn by people and political entities. One major threat to the health of our national forests is non-native invasive species (Bosworth, 2004). These problems occur with or without notice on private forestlands. Invasive plants out-compete native vegetation for growing space and resources, and can alter species composition. This can displace wildlife that is reliant upon the native ecosystem that existed prior to the invasion of these aggressive alien plants. There is a variety of non-native pests and insects, accidentally introduced, that are causing the decimation of important tree species. Currently, two examples of pests that have drawn much attention are the emerald ash borer and the hemlock woolly adelgid. Without action on both private and public forestlands, these issues cannot be effectively managed and the rich diversity that exists in West Virginia is at risk.

Another issue that may pose a threat to forestlands is suburban development caused by population growth. While much of West Virginia remains undeveloped with vast forestland, areas such as the New River Gorge and Canaan Valley have been subject to second home development (Smith, 2007). There was an 11 percent average population increase in the eastern panhandle counties between 2000 and 2006 (U.S. Census, 2006). Because of this area's relatively close location to the Baltimore and D.C. metropolitan centers, a substantial amount of land is being used for second or retirement homes, weekend recreational use, and property by outside residents (Rosenberger et al., 2002). Hailu (2002) reported that the population growth in the eastern panhandle may be attributed to the development of 'bedroom communities' where people who work in the metropolitan areas of Maryland, Virginia, and D.C. are residing there seeking lower property values and a higher quality of life. Overall, the rest of the state experienced negative or very small increases in population.

As people escape to the outskirts of densely populated areas, they bring with them the desire for a higher quality of life in the peaceful countryside (Egan \& Luloff, 2000). The ideologies introduced by individuals from urban environments will create a more diverse political atmosphere. Their use of the forest may be limited to recreation, aesthetics and 
sightseeing, thus changes may occur within the utilization of forest resources for economic purposes. Concern for aesthetics and conservation can affect timber production and other management practices that are not harmonious with the objectives of the new populations.

A study of communities surrounding Charlottesville, Virginia by Wear and others (1999) suggested that as the number of people per square mile increases, the probability of forest management decreases. Other literature has addressed the topic of the urban-rural interface and possible implications to resource management. Egan and Luloff (2000) acknowledged that rural places are subject to changes in attitudes towards the management and use of forests. These changes have influenced the role of forests in rural economies and social structure and have also led to the development of forestry policy.

\section{Characteristics and Trends Associated with NIPF Owners}

The number and acreage of private forestland owners has increased through the years. Birch (1996) reported a six percent increase between 1978 and 1994 in individual ownerships and a four percent increase in the acreage owned by this group. He noted that the new generation of forestland owners were 'younger, better educated, and had higher incomes' than ten years prior (Birch, 1996). Between the 1978 and 1994 national studies of NIPF owners, there was an increase in retiree ownerships $(+3 \%)$ and the number of holdings by persons employed in the 'other' category $(+9 \%)$. The other category in these studies were comprised of service workers, homemakers, and non-blue collar and -white collar professions. The majority of NIPF owners lived within a mile from their forestland holdings (Birch, 1996).

In the most recent national study of non-industrial private forest owners, or 'family forest' owners, Butler and Leatherberry (2004) concluded that the number of owners 65 and older increased by 34 percent between 1993 and 2003, and the average age of NIPF owners was 60 years. Nearly two-thirds (62\%) had some college education (Butler \& Leatherberry, 2004). Seven out of 10 owners reside within one mile of their forest and twelve percent of owners have a secondary home located within a mile of their forestland (Butler \& Leatherberry, 2004).

Butler and Leatherberry (2004) found that the probability of harvesting, seeking management advice, and establishing a management plan increases as the size of a landowner's property increases (see also Wear et al., 1999; Sampson, 2000). Forest fragmentation and parcelization will affect management of non-industrial private forests in years to come. Butler 
(2008) emphasized the importance of the size of forest holdings, as this ownership attribute is positively correlated with having a written forest management plan, having received forest management advice, and conducting commercial timber harvests. Birch (1996) reported an increase in the number of individuals owning forestland, while there was a decrease in the average size of their holdings between 1978 and 1993. For example, nationally, the number of ownerships of 10 to 49 acres increased from 1.2 million in 1978 to 2.8 million in 1994 (Birch, 1996). These ownerships totaled 60 million acres in 1993, an increase of 32 million acres from 1978 estimates (Birch, 1996).

By 2010, 95 percent of private ownerships are expected to be broken into properties less than 100 acres with an average ownership of about 17 acres (DeCoster, 1998). The more recent survey of NIPF owners reported a similar trend associated with individual ownerships. Based on the 2003 National Woodland Owners Survey, Butler and Leatherberry concluded there was an increase of $11 \%$ in the number NIPF ownership between 1993 and 2003 (Butler and Leatherberry, 2006). The majority of landowners (89\%) own between 1-49 acres; forestland owners with holdings greater than 50 acres only comprise $11 \%$ of the NIPF owners. Properties less than 50 acres had the largest increase in the number of new landowners, meaning that more and more forestland owners are controlling smaller tracts of land.

At the national level, only 3 percent of family forest owners have a management plan for their property and only 16 percent sought management advice from a professional (Butler \& Leatherberry, 2004). The most recent National Woodland Owners Survey (NWOS) reported that only 4 percent of forestland owners in the Northern region, which includes WV, have written management plans and 13 percent have sought management advice over the 5 years prior to the study (Butler \& Leatherberry, 2004). In addition, nearly one-quarter (22\%) of NIPF owners who have harvested in the Northern region obtained advice from a professional during their most recent timber operation (Butler \& Leatherberry, 2004).

Birch (1996) found that the main reasons for ownership involved the property being used as part of a residence and/or farm, for aesthetic enjoyment, or for domestic use. Revisited by Butler in 2006, reasons for owning land have not changed significantly, but now include owning land to pass to heirs, and forest land investment. The objective for owning land for timber production is not cited as frequently as in past years. 


\section{Development of Programs and Policy to Assist NIPF Owners}

Throughout the years, programs and policies have evolved as the understanding of forest development and impacts of past exploitive harvesting practices have increased. Concerns of timber shortages were stirring by the end of the 1800 s due to the heavy timbering carried out to fuel commercial development in the eastern United States (Sampson \& DeCoster, 1997; Stoddard, 1942). Williams (1989) estimated that the original forest cover (between 822 to 850 million acres) in the country had been reduced to approximately 470 million acres by 1920 , of which only 138 million acres were of 'original condition', or virgin, forests. The degradation of lands once covered with a seemingly endless supply of natural resources, created an environment in which government and industry were concerned about timber shortages. Regulation was needed on public lands and policy was needed to help industry, as well as private forest owners, conserve and responsibly manage their land for the greater good of the country. While the timber industry is credited with the establishment of the Tree Farm Program, much of the development of these programs is due to federal governmental efforts.

The United States Department of Agriculture (USDA) Division of Forestry was established in 1880 to provide information about forests and forest industry (Best \& Wayburn, 2001). This marked the beginning of a growing movement to assist and encourage nonindustrial private forest landowners to sustainably manage their forestlands to ensure future timber supply, and also to conserve soil and water resources. Non-industrial private forests (NIPF) are forestlands owned by private individuals, groups, corporations, or tribes, who do not maintain forested property for the sole purpose of timber production. In 1898, Gifford Pinchot, a key figure in the movement of forest conservation, was named the head of the Division and was focused on not only providing information, but actively assisting NIPF owners in sustainable and practical forest management (Best \& Wayburn, 2001). Even with limited staff, the Division assessed 400,000 acres of private forests in 10 states during the first year of operation under Pinchot (Stoddard, 1961).

Due to the heavy harvesting, several program existed through the 1900s to encourage tree planting on both federal and private lands. Extensive efforts were made to restore forests that had been mismanaged:

"The Civilian Conservation Corps (CCC) planted 2.3 million acres of public and private lands to trees from the mid-1930s to the mid-1940s. 
The Soil Bank Program planted 2.2 million acres of private crop lands to tree from 1956 to 1961. The Conservation Reserve Program (CRP) planted 2.8 million acres on highly erodible lands during the late 1980's. Annual tree planting in the United States has increased from 140,000 acres in 1930 to 2.6 million acres in 1998 (p. 24, Moulton \& Hernandez, 1999)".

Federal programs have also been created to help share the costs of applying sound, longterm management to private forestlands. The earliest federal cost-share program incorporating forestry practices was the Agricultural Conservation Program (ACP), authorized as part of the Soil Conservation and Domestic Allotment Act of 1936 (Cubbage et al., 1993). As part of the 1936 Act, federal monies were allocated to private landowners through local administrating committees to encourage them to use practices that would conserve soil (Sampson \& DeCoster, 1997). Along with other practices to achieve the goals of soil and water conservation, forestry practices eligible for cost-share dollars under this program included tree planting and timber stand improvement (TSI) (Skok \& Gregersen, 1975). Practices specified under TSI funding included pruning, thinning, crop-tree release, removal of undesirable trees or vegetation, and livestock exclusion fencing (James \& Schallau, 1961).

Based on annual summaries recorded from 1946 to 1958 , a total of only 1.1 percent of ACP funding was allocated towards forestry-related practices (James \& Schallau, 1961). Funding for forestry declined from the 1960's, resulting in high competition for cost-share dollars available to private landowners. Compounding the competition for financial resources was a lack of concern from program administrators at the local level to use cost-share dollars for forestry practices (Cubbage et al., 1993). With the greatest proportion of funding for forestry practices allocated to tree planting, 7.2 million acres were planted through ACP cost-shared dollars (1936-1992) and over three-quarters remained in forest use in 1992 ([Kurtz et al., 1994], in Sampson \& DeCoster, 1997).

Realizing the negative public opinion towards the timber industry due to a growing conservation movement in the early 1900s and their historical mismanagement of forest resources, timber companies began to remediate the environmental degradation that resulted from overharvesting. The rapid decline in mature virgin stands nationally forced industry to 
restock and grow the stands they had decimated to ensure future timber production (Sharp, 1949).

Due to the amount of forest resources lost on private lands, the timber industry began to play a role in encouraging private landholders to conserve and enhance their forest resources (Sharp, 1949). As an attempt to prevent fire, secure sustainability of vast private forestlands, and to shift the public's image of the forest industry towards 'conservation-sound management', the American Tree Farm System (ATFS) was created. This program originated in the northwestern United States in 1941 when the Weyerhaeuser Timber Company coined their reforestation project a 'tree farm' (Sharp, 1949). The buzz of conservation and the esteemed recognition related to this program stimulated a national movement for private forestland owners to enroll and become a certified Tree Farm.

Initially, many large industry forestlands were certified, wanting to improve their public image. After only a year of operation, the program had enrolled and certified 5 million acres (Sharp, 1949). The high rate of enrollment led to the questionability of the certification standards of the utilization of sustainable forestry practices were being inspected and assessed on enrolled properties (Sharp, 1949). Coupled with this and the threat of federal regulation of the industry to ensure proper management, the program evolved and became more and more stringent in its standards and qualifications for Tree Farm certification.

Still viable today, the ATFS serves as an internationally-known forest certification system and supports private landowners holding 24 million acres of family forests (American Tree Farm System, 2004). Since its inception, programs carried out under the American Tree Farm System have strived to encourage forestland owners to sustainably manage their woodlands. Once focused on tree planting and increasing timber productivity on forestlands, the effectiveness of this program is attributed to an increased focus on the landowner's desired landuses and needs (American Tree Farm System, 2004).

At the federal level, Congress enacted the Forestry Incentives Program (FIP) in the 1973 Agriculture and Consumer Protection Act to provide private landowners a cost-share program solely to help increase the nation's timber supply and improve the management of existing forests on non-industrial private forestlands (Sampson \& DeCoster, 1997). Practices approved through this program included reforestation, timber stand improvement (TSI), site preparation for natural regeneration, and firebreak construction (Sampson \& DeCoster, 1997). Of the 3.7 
million acres that had received cost-share dollars from FIP through 1990, 2.5 million had been planted with trees and TSI was performed on 1.2 million (Cubbage et al., 1993). This program was authorized until the Farm Bill of 2002, which replaced FIP with the much broader Forest Land Enhancement Program (FLEP).

Prior to the 1970s, few researchers deviated from attempting to understand the role that private forestlands played in securing timber supplies as a function of demographic and forestland holding characteristics (Cubbage et al, 1993; Egan, 1993, 1997; Best \& Wayburn, 2001). One of the earliest studies conducted by C.H. Stoddard Jr. (1942), which sought to understand other management objectives important to non-industrial private forestland owners (NIPF), found that landowners in the Northern Lake States tended to be interested in recreation, wildlife habitat, and non-timber forest products. Only 43 percent of New England forestland owners held their land for timber values, while the remaining proportion held forestland for recreational use, the purpose of merely owning land, as part of the residence, and other nontimber related reasons (Barraclough \& Rettie, 1950).

Stoddard (1961) reported that farmers that also held forestlands saw their woodlots as merely a part of the residence and rarely applied active management. While limitations exist in the management of small private forests (i.e. costs, lack of resources, tract sizes, limited income), he called for the creation of programs that would help landowners capitalize on the potential of the forests, with consideration of the forest characteristics and owner activities (recreation, wildlife management, other interests), in addition to the demand for forest products. Past programs were designed under the impression that NIPF owners had different attitudes than the general public towards land management and that their forests were held due to their interest in

timber production, when in reality this segment of the population was not substantially different and many do not have an interest in harvesting (Bourke \& Luloff, 1994). Thus, the development of programs focused on these land uses had been ineffective and the future of assisting NIPF owners was dependent upon providing them guidance and knowledge to responsibly manage their land with focus on their objectives (Bourke \& Luloff, 1994)

\section{Forest Stewardship Program and Related Cost-share Programs}

The Farm Bill of 1990 authorized the first forestry title, which devoted a portion of the Farm Bill explicitly for forestry-related programs and policy. This bill contained programs 
oriented towards long-term forest management of non-industrial private forest (NIPF) lands (Best \& Wayburn, 2001). NIPF lands are those owned by any private individual, group association, corporation, Indian tribe, or other private legal entity and also includes rural lands with existing tree cover or suitable for growing trees (USDA Forest Service, 2005). Within this legislation, the Forest Stewardship Program (FSP) was created to assist private forest landowners develop management plans for their forestlands with the help of a certified forester.

Administered by state forestry agencies and funded through the USFS, this program provides educational, technical, and monetary assistance to manage NIPFs sustainably. Sustainable forest management entails the long-term maintenance or enhancement of multiple forest resources, such as forests, wildlife, water, soil, and other amenities that forestlands supply (USDA Forest Service, 2005). Although this program is voluntary, the landowner agrees to manage this forestland in accordance to the approved stewardship plan to enroll in the program. Stewardship, or management, plans are developed to support the objectives of the landowner and serve as a guide for implementing practices that achieve their property-specific goals. Once plans are written by a forester and accepted by the landowner, they are reviewed by the state forestry agency for approval. Because of the voluntary nature of the program and the lack of resources needed to monitor landowner progress towards meeting the management objectives of their approved stewardship plan on the ground, the number of plans written and acreage enrolled may not truly describe the success of the program. The extent that participants are successfully implementing practices as recommended in their plan will define its effectiveness and influence on management of NIPF lands (Egan et al., 2001; USD A Forest Service, 2005).

In 1992, nearly half (48\%) of the United States' 737 million acres of forests were classified as nonindustrial private forest lands ([National Research Council, 1998], in Esseks \& Moulton, 2000). Because of the importance of these lands, water and soil conservation, and other products and environmental services, as well as earlier research showing that NIPF owners are interested in more that timber production, the federal government created the FSP to provide landowners with the technical assistance, education, and resources available to sustainably manage their woodlands. Intentions were that by establishing a program that catered to the diverse goals and objectives of landowners, more active and intentional management would result (Esseks \& Moulton, 2000; Best \& Wayburn, 2001). By 1997, national participation in the 
FSP had resulted in the preparation of over 130,000 plans for an estimated 16.5 million acres (Esseks \& Moulton, 2000).

The first cost-share program associated with the FSP was the Stewardship Incentive Program (SIP), which was included in the Farm Bill of 1990. Depending on the amount of federal dollars that states received to assist NIPF owners, participants could receive up to seventy-five percent reimbursement for practice implementation. Under the SIP, a landowner with an FSP plan could apply for monetary assistance to apply practices on the ground, including reforestation/afforestation, the establishment, maintenance, and renovation of windbreaks and hedgerows, protection/improvement of riparian areas and wetlands, fisheries habitat enhancement, wildlife habitat enhancement, and forest recreation enhancement (Cubbage et al., 1993). Cost-share dollars were also available for management plan development in the case that the landowner did not have one in place (Cubbage et al., 1993).

The success of SIP varied regionally and by state. In South Carolina, 62 percent of landowners had applied for SIP cost-share assistance to implement their stewardship plans (Melfie et al., 1997). SIP was also successful in West Virginia until funding ceased in 1997. Within the four or five years that the program was administered, the state was able to fund over \$2 million for various practices, including timber production practices and wildlife habitat enhancement (Whipkey, 2001). The cost-share program was well received in the state and landowners were very willing to pay for the remaining cost of practice implementation (Whipkey, 2001). Nationally, between 44 to $58 \%$ of FSP participants across the four regions of the country had received cost-share assistance for plan implementation (Esseks \& Moulton, 2000).

Through time, other programs have been initiated to offer cost-share assistance to NIPF owners. In 1996, the Environmental Quality Program (EQIP) was authorized to provide some forestry-related assistance. Administered by the National Resource Conservation Service (NRCS) and the Farm Service Agency (FSA), practices eligible for cost-share funding include the improvement and conservation for at-risk wildlife species, as well as soil erosion/sedimentation control and conservation of ground and surface water (NRCS, 2004a). These and other agricultural-focused practices may receive up to seventy-five percent cost-share assistance. Although not specifying the extent of assistance provided to FSP participants, the NRCS reported in 2004 that 51.5 million acres were enrolled into the program, and nearly $\$ 1.08$ 
billion had been obligated to aid in management of agricultural land. This program has been reauthorized by the Farm Bill of 2008 and is currently being reorganized to include more forest practices. As of this study, final rules have not been released to establish the allocation of federal funds.

The Wildlife Habitat Incentives Program (WHIP) is also administered by the NRCS and was authorized in 1996 and was reauthorized through the 2008 Farm Bill. This program is focused on providing cost-share assistance to private landowners to create or enhance wildlife habitat for species of national, State, Tribal, and local significance (NRCS, 2004b). Since 1998, the NRCS reported in 2004 that 14,700 landowners have enrolled in the program, covering 2.3 million acres. Some sensitive species that have benefited from this program include the Karnerblue butterfly (Lycaeides melissa samuelis), Eastern collared lizard (Crotaphytus collaris), and grasshopper sparrow (Ammodramus savannarum).

As a replacement to SIP and FIP, the most recent cost-share program associated with the FSP has been the Forest Land Enhancement Program (FLEP). Authorized in 2002 (with no further authorization in the 2008 Farm Bill), this program offered much of the same extensive list of forestry practices eligible for cost-share dollars as in the past, but it sought to combine the most effective qualities of earlier programs. Title VIII of the 2002 Farm Bill authorized FLEP's assistance to NIPF owners to sustain the long-term productivity of timber and non-timber resources. Practices eligible for FLEP funding included afforestation and reforestation, improvement of poorly stocked stands, timber stand improvement, practices necessary to improve seedling growth and survival, and growth enhancement practices, as well as practices that reduce risks to forest health such as fire, insects, invasive species, disease, and weather.

Historically, common limiting factors of federal programs to assist NIPF owners are program awareness and the availability of adequate and consistent funding (Kilagore et al., 2007). In 1954-55, between 82 and 97 percent of NIPF owners in northern Michigan were unaware of the existence of assistance programs, such as the forestry extension program, service forestry program, and the Agricultural Conservation Program (ACP) (Yoho \& James, 1958). Many landowners were not taking advantage of forester's services and technical assistance because they either did not know how a forester could help them or that they did not know that such services existed (Anderson, 1960). His study of southern small forestland owners also indicated that owners with lower incomes would have employed assistance program for tree 
planting on their lands if they had known of their existence (Anderson 1960). More recently, some studies have shown that limited numbers of forest landowners are aware of forestry assistance programs (Kilagore et al., 2002). The evaluation of the West Virginia FSP found that nearly one-half of respondents were not enrolled in any other forest landowner assistance programs (Jennings \& McGill, 2005). The one exception was the Managed Timberland Tax incentive, with 17 percent of respondents participating in this program as well as the FSP, the most often reported program used was the Stewardship Incentive Program, with only 16 percent of participants using this cost-share program (Jennings \& McGill, 2005). Conversely, another study of the FSP found that, nationally, 50 percent of respondents had received cost-share assistance to implement their stewardship plan (Esseks \& Moulton, 2001).

A study of the influence of financial incentive programs found that the appeal and awareness of programs that were better-funded were rated highest by NIPF owners across the country (Kilagore et al., 2007). While no program was highly rated (above 3.5 of a 4-point scale) in its appeal or landowner awareness of its existence, the FSP and FLEP were rated the highest in respect to these characteristics (Kilagore et al., 2007). These programs were also rated moderately to highly effective in encouraging overall sustainability (Kilagore et al., 2007). In terms of the ability to assist NIPF owners to meet a variety of management and ownership objectives, the FSP and FLEP were rated more highly than any other federal program (Kilagore et al., 2007).

\section{Evaluating the Forest Stewardship Program}

\section{Plan Implementation}

A national study of the FSP revealed that a large proportion (84\%) of participants across the country had begun to implement some of the practices recommended in stewardship plans (Esseks \& Moulton, 2001). Among practices surveyed, 'growing or caring for trees' was reported with the highest implementation rates across the country. Specifically, this classification included planting, thinning, and fighting forest disease or pests. 'Improving or preserving forestland for wildlife' ranked second and 'Harvesting or marketing trees' ranked third most frequently implemented practices at the national level.

Since the inception of FSP, several assessments have been conducted to evaluate the effectiveness of the program in terms of practice application. Based on the first evaluation of 
West Virginia's FSP, the most frequently reported practices implemented were timber stand improvement and harvesting, with just over one-fifth of respondents reporting practice application (Egan et al., 2001). Nineteen percent of respondents had applied grapevine removal, which was the third most frequently recommended practice. Wildlife habitat improvement was implemented by 15 percent of respondents and was the fourth most commonly recommended practice. Ten years after the establishment of the FSP, another study was conducted to evaluate the implementation of recommended practices in West Virginia (Jennings, 2003). High implementation of management practices were found among WV FSP participants (Jennings \& McGill, 2005). Practices relating to wildlife habitat management, timber stand improvement, and the development of recreational opportunities proved to be the most often applied practices. However, all ten practices in question were applied on nearly 50 percent or more of the occasions it was recommended (Jennings \& McGill, 2005).

\section{Factors Influencing Practice Application}

A national evaluation of the program found that 65 percent of participants had not received advice from a specialist about managing forestland prior to enrollment in the FSP. For many participants (56\%), the program provided a venue for forestland owners to make contact with a natural resource professional and the majority (88\%) of participants felt that the program provided a valuable source of information (Jennings \& McGill, 2005). The establishment of a management plan is significantly associated with the implementation of forest management practices, as well as the extent and number of practices applied (Baughman \& Updegraff, 2002).

Over one half of respondents in all regions reported that they had applied at least one new practice on their land that they had not prior to enrollment. Collectively, there was also a 15 percent increase in participants across all regions stating that they had received or would pursue professional advice about land management after enrollment in the FSP (Esseks \& Moulton, 2001). This trend was also evident in terms of participants subscribing to informative materials, such as magazines, online resources, and newsletters, with an increase from 17 percent before enrollment to 45 percent afterwards (Esseks \& Moulton, 2001). Although other factors may play a role in behavioral changes, the indication that these changes occurred after program enrollment may reflect the success of the program (Esseks \& Moulton, 2001) 
Researchers have investigated the relationships between landowner and participation characteristics and their tendency to implement forest stewardship plans. Landowner characteristics included items such as income, age, years owned, ownership objectives, and tenure. Participation characteristics involved information about stewardship plan author, satisfaction with written plan, certainty that recommendation will meet management objectives, recommendation of practices, and so on. Practice implementation has been closely linked to the recommendation of forest management practices in stewardship plans (Egan et al, 1997; Esseks \& Moulton, 2001; Jennings \& McGill, 2005). The use of other private landowner assistance programs, such as Tree Farm program, cost-share assistance, and tax incentives, were significantly related to the application of practices by WV FSP participants (Jennings \& McGill, 2005). In addition, participants that received follow-up technical assistance were more likely to apply more than one practice to achieve management objectives (Esseks \& Moulton, 2001).

In addition, there was a strong association between the implementation of recommended practices related to the management objectives of the landowner. Another study of FS programs in six states (IL, IN, IA, MI, MN, and WI) in the north central region found similar results, as owners that held forestlands for income and sale of forest products were more likely to implement timber stand improvement and harvesting, where as those who owned forestland as part of their farm reported higher rates of implementation for soil protection (Baughman \& Updegraff, 2002). The certainty that the FSP participant felt that their stewardship plan would meet their objectives was also significant in determining practice implementation (Jennings \& McGill, 2005).

\section{Participants and their Evaluation of the Forest Stewardship Program}

Reasons for enrollment in South Carolina's FSP were cost-share assistance, professional assistance, concern for future generations, and the integration of multiple-use management (Melfie et al., 1997). Baughman and Updegraff (2001) found that over one-half of respondents obtained a stewardship plan due to their interest in better stewardship and forest manage ment, in addition to learning more about their property. Cost-share and incentive programs were also important reasons for these owners, with nearly one-quarter of respondents reporting this as a reason for the establishment of a stewardship plan (Baughman \& Updegraff, 2001). Similar findings were found among WV FSP participants (Jennings \& McGill, 2005). 
When asked about the ease of understanding their written plan and the enrollment process, the majority of respondents reported their plans (93\%), as well as associated paperwork (85\%), to be very easy or easy to understand (Baughman \& Updegraff, 2001). In terms of follow-up technical advice, just below two-thirds (62\%) of respondents had received such assistance. Three-quarters (76\%) of advice given was from a public agency and nearly all respondents $(95 \%)$ rated the follow-up advice information they received as moderately to highly useful.

Because each state has control over the administration of the FSP in following the national guidelines and standards of the program, evaluations have been completed at the state level to understand the level of satisfaction of program participants. In West Virginia, research has shown that there are high levels of satisfaction with the Forest Stewardship program, the foresters who wrote landowners' stewardship plans, and the written stewardship plan (Egan at al., 2001; Jennings \& McGill, 2005). There was a high level of satisfaction among participants who have completed or started to complete some of the recommendations in the plans for their property (Jennings \& McGill, 2005). An evaluation of the FSP in north central states revealed that participants rated the visit with a forester, as well as their written plan and its composition very high (Baughman \& Updegraff, 2002). When asked the value of different types of help that would enable participants to complete recommendations in stewardship plans, respondents of this study indicated that they value more government cost-sharing, more professional advice, and more training to complete practices.

Research efforts that have served to monitor the efficiency of federal forestry cost-share programs have explored landowners' dissatisfaction with the FSP and have elicited suggestions from participants for improvements to the program. The most often reported reasons for dissatisfaction were increases in property tax for filing a FS plan, lack of foresters to be able to fulfill the demand for stewardship advice, and landowners' lack of funds to implement recommended practices (Egan et al., 1997; Baughman \& Updegraff, 2001).

\section{Evaluating the Reliability of Landowner Responses}

Aside from understanding the management behaviors, attitudes, and characteristics of NIPF owners and participants of the FSP, research has pointed to several biases that may be introduced by using only one method of data collection for research of poorly understood social 
phenomena (Egan et al., 1995). Esseks and Moulton (2001), in recognizing the high percentages of practice implementation on a national level, noted that the extent of plan implementation may be more exaggerated due to nonresponse error. Because the extent of plan implementation does not represent all FSP participants, the extent of implementation of participants that did not partake in the study is unknown.

Addressing such issues, research has been conducted using multiple data collection methods to evaluate the reliability of landowner survey responses. Based on their reports of conducting a timber harvest during a mail survey, only 86 percent of Pennsylvanian NIPF owners confirmed that they had indeed harvested when interviewed by telephone only eight months later (Egan \& Jones, 1995). Ten percent of respondents that had originally reported harvesting stated that they had never harvested timber on their property, and one respondent actually stated that they did not even own forestland (Egan \& Jones, 1995).

The 1997 assessment of the effectiveness of the FSP in West Virginia found that only 88 percent of survey participants that stated that had harvested since their FSP enrollment in the initial survey responded consistently in the follow-up assessment. Eight percent of these respondents had harvested prior to the development of their stewardship plan, 2 percent said they were involved in a non-commercial harvest, and another 2 percent had not harvested at any time. There may be several explanations for these discrepancies, but such inconsistencies among survey responses can supply social researchers in the field of natural resources with incorrect data leading to unreliable inferences, without on-site monitoring.

\section{Study Objectives}

One purpose of this study is to provide clarity about the implementation that is occurring on NIPF lands enrolled in the Forest Stewardship Program by elaborating on findings from a mail survey conducted by Jennings (2003) on the implementation of recommended management practices on forestlands enrolled in the West Virginia Forest Stewardship Program. The following research questions were investigated:

Q1.1 To what extent are recommended forest management practices being implemented on the ground? Is there a relationship between a practice recommendation and its implementation and/or the extent of land area (acres/miles) on which it is applied? 
Q1.2 Regardless of whether or not practices were recommended in a management plan, to what extent are practices implemented and are there relationships among practices in terms of the extent (acres/miles) to which they are applied?

Q1.3 Are there differences in the extent of practice application (acres/miles) among landowners with differing ownership objectives?

Q1.4 Do cost-share programs influence whether practices are implemented? Is there a difference in the extent of application (acres/miles) between those who use costshare programs and those who do not?

The second purpose of this study is to validate the responses given by participants of the previous study of the West Virginia FSP (Jennings, 2003) and to understand the inconsistencies that may occur when research is limited to one survey method. To address this objective, these research questions were asked:

Q2.1 Is there consistency in the responses given in this survey and the previous study by Jennings? By using multiple surveys to find greater detail in responses from landowners, can a more valid and accurate representation of the population be found? 


\section{CHAPTER III}

\section{METHODOLOGY}

\section{Survey Development and Sample Establishment}

Telephone survey questions were formulated in a collaborative effort between faculty from the WVU Division of Forestry and the WVU Division of Sociology and Anthropology. The questionnaire was modeled after the earlier WV FSP study (Jennings, 2003). In contrast to the earlier study that was geared towards understanding landowner demographics, levels of satisfaction with various aspects of the program, motivation for enrollment, implementation of recommended practices, and participation in other NIPF assistance programs, the telephone questionnaire was designed to have participants provide information about the extent of practice application (acres or miles) and the use of cost-share programs to implement practices, as well as the amount of time that had passed since practice application. Questions were designed to get an assessment of the amount of land upon which a practice had been implemented, providing data to address the first objective of this study (pg 22). Respondents who had not applied one of the ten practices were then asked about their primary reasons for not implementing them. Responses available to those not implementing certain practices were: 1) monetary constraints 2) time constraints or 3) unsuitable conditions to implement practice. Prior to asking respondents about their recommended and implemented practices, other questions related to the usefulness of their stewardship plan and the frequency of plan referral, how their forestland was acquired, the importance of various landownership objectives, practices recommended in their stewardship plan, and motivations for management application. The instrument was reviewed and approved by the WVU Office of Research Compliance.

Survey participants were selected from a list of 3,092 landowners who were enrolled in the West Virginia FSP. This list was also the source for the earlier mail survey (Jennings, 2003). A letter explaining the upcoming telephone survey study, a summary of the previous FSP study by Jennings (2003), and a postage-paid “non-participant” postcard were sent to all enrolled households that had a telephone number listed in the FSP participant database $(n=2,131)$. Recipients were asked to return the postcard if they did not wish to participate in the study and were asked to indicate their reason(s) for non-participation. Reasons for non-participation listed 
on the postcard included: 1) no longer in program, 2) never enrolled, 3) sold property, 4) no time, 5) do not wish to participate, and 6) other reason.

Of the 2,131 letters mail to FSP participants, 408 were returned due to incorrect addresses or the recipient had passed away and 213 postcards were returned by FSP participants that did not wish to participate in the study (Table 1). Individuals that returned postcards were removed from the calling list.

Table 1. Reasons for non-participation, based on pre-mailing postcard returns.

\begin{tabular}{lcc}
\hline Reason & $\mathrm{n}$ & $\%$ \\
\hline Do not wish to participate & 99 & 46 \\
Other & 45 & 21 \\
No longer in program & 36 & 17 \\
No time & 31 & 15 \\
Sold property & 31 & 15 \\
Never did enroll & 15 & 7 \\
\hline
\end{tabular}

Note: Percentages do not total to $100 \%$ due to multiple responses.

To address the second study objective of validating responses (pg 23) given by participants of the previous mail survey, it was essential to link the mail-questionnaire data with the telephone survey data. The remaining contacts were designated the same identification number from the previous mail survey to maintain a linking variable with the database from the Jennings (2003) survey. Linking these two databases also made it possible to avoid repetitive questions that the respondent may have answered in the previous mail survey and assured the confidentiality of respondents' personal information that had been collected in the earlier Jennings (2003) survey. The resulting database of 1,510 randomly-ordered telephone numbers was supplied to the WVU Survey Research Center (SRC) who had been contracted to conduct the telephone interviews. The SRC selected just over one-half (54\%) of the contact list for the survey $(n=820)$ in an attempt to achieve a sufficient response rate. The response rate was calculated using the percent of the total number of attempts made $(n=820)$ that resulted in completed interviews ( $\mathrm{n}=327)$ (AAPOR, 2008). The cooperation rate was calculated using the total number of successful contacts $(n=437)$ that yielded a completed interview $(n=327)$ (AAPOR, 2008). 


\section{Data Collection}

Data collection was conducted from September to mid-December of 2005 through the Survey Research Center (SRC) at West Virginia University, Morgantown, WV. Two interviewers were trained to conduct the telephone survey prior to data collection. Later on in the data collection process, these interviewers were replaced due to their time constraints to conduct the survey. The telephone interviews were conducted from 10:00 am to 8:30 pm, three days per week. Three attempts were made to contact each of the randomly selected FSP participants. If no contact was made during the second attempt, the interviewer left a message explaining the purpose of the call and stated that one additional attempt would be made. Contact attempts that failed after three trials were replaced by the next phone number on the randomlygenerated list of contacts.

As telephone interviews were completed, responses were recorded on Scantron sheets, and electronically scanned to develop the database in Microsoft Excel. Due to missing and duplicate respondent identification numbers in the final merged database, 26 duplicate and 6 missing cases were removed. During this data conversion, one response related to whether or not the development of recreational opportunities was recommended in the respondents' stewardship plan was lost during the electronic transfer from the Scantron sheet to the Excel database. The telephone-based survey database and the mail survey database were merged using Statistical Analysis Software (SAS Institute, 2003) using the common survey identification number. Once merged, the data were transferred into a Microsoft Excel spreadsheet.

\section{Data Analysis}

Statistical Package for Social Sciences (SPSS) software was used to analyze the final merged response database. Descriptive statistics were used to understand the demographic characteristics of the respondents, the reported usefulness of and referral to stewardship plans, land ownership objectives, how forestland was acquired, and motivations to implement forest management. Descriptive statistics were also used to understand the recommended and implemented practices on these FSP properties, the extent of application of these practices, constraints to applying forest management practices, the amount of time that had passed since application, and the use of cost-share programs.

Only respondents that initially answered affirmatively that a specific practice had been applied were used to assess relationships among practice extent, time since practice 
implementation, and the use of cost-share assistance. If they stated that they did not apply a practice, any other questions relating to implementation of that practice, such as the acres/miles of application, time that had since passed, and the use of cost-share programs, were excluded from analysis. Similarly, only respondents that reported the practice was not applied on their land were used in the analysis of challenges and constraints that kept them from implementing this type of forest management.

Contingency tables and Pearson's chi square statistic were used to test the relationship between practice recommendation in respondents' stewardship plan and practice implementation. This will show if there is a significant relationship between practice application and practice recommendation, as found in previous studies of the FSP (Egan et al., 1997; Esseks \& Moulton, 2001; Jennings \& McGill, 2005). To better understand the association between applied practices, a bivariate correlation (using Pearson's correlation coefficient) was used to find relationships among the degree (acres/miles) to which the each forest management practice was applied. Independent t-tests were used to test for differences in the extent of practice application by landowners using or in the absence of cost-share programs. This test will show if practices applied under cost-share assistance are implemented on greater or lesser extent.

Baughman and Updegraff (2002) found significant differences in the extent of practice application and reasons for forestland ownership in the north central United States. Analyses were conducted to corroborate findings from other studies that have explored landowner behavior. Landownership objectives surveyed included: 1) Maintain and improve investment value, 2) Generate primary income, 3) Provide supplementary income, 4) Create wildlife habitat, 5) Maintain and improve appearance, 6) Provide for recreational opportunities, 7) Maintain and improve water quality, and 8) Prevent soil loss and erosion. Because of the low response of landowners reporting some objectives as most important (Table 15), respondents were classified into groups based on their primary landownership objective. In Objective Group 1, responses were combined for maintain/improve investment value, generate primary income, and provide supplementary income $(n=97)$. Objective Group 2 consisted of responses for the objectives create wildlife habitat, maintain/improve appearance, and provide for recreational opportunities as the most important landownership objective $(n=90)$. In addition, prevent soil loss and erosion and maintain/improve water quality were combined to form Objective Group 3 (n=67). A oneway analysis of variance (ANOVA) was used to test for differences in acreage applied with 
various forestry practices among respondents categorized into the three landowner objective groups.

The one-way ANOVA was first performed using the raw values reported by respondents in acres or miles of application extent for each practice. Levene's test for equality of variance showed that four of the ten practices had significantly different variances which could create error in the comparison of means of practice application between objective groups. Extent of application data were then transformed using the natural log function, and the resulting test for homogeneity of variances showed only one (extent of wildlife habitat improvement) variable with significantly different variances between the combined objective groups. By transforming data using natural logarithms, their distributions relative to the combined objective groups become more linear (Ott, 1988). Using the natural log-transformed values, ANOVA showed if there were significant differences in practice application among the objectives that landowners felt were most important. Bonferroni's post hoc test was used to explore differences among the landownership groups (Moore \& McCabe, 2006).

As mentioned in the descriptions of the second study objective, research on landowner responses has found that using one method of data collection can produce results that provide an inaccurate representation of the study population (Egan, 1993; Egan et al., 1995; Egan \& Jones, 1995; Egan et al., 2001). To evaluate the consistency of practice implementation responses in the West Virginia FSP evaluations, responses given by telephone survey participants that participated in the previously mail FSP survey were examined. Respondents that had participated in both the mail and telephone survey represented 65 percent $(n=191)$ of the total telephone survey population. Respondents that reported that someone else in the household had completed the mail survey in 2003 or that they did not remember who completed it were removed from this portion of the analysis.

The mail survey asked respondents if each of the recommended practices were completed 1) fully, 2) almost, 3) somewhat, or 4) not at all (Jennings, 2003). Forestry practices reported by respondents who had indicated in the mail questionnaire that they had at least partially implemented (fully, almost, and somewhat) recommended practices were compared to those same practices reported in the telephone survey.

"Consistent responses" were deemed to be those that reported either having applied a forestry practice or not applying a practice in both surveys (Table 2). Cases in which 
respondents reported that they had not implemented a particular forestry practice in the mail survey, but reported that they had applied that practice in the telephone survey were further analyzed to see if the timing of such implementation explained the differences in responses. Respondents that reported practice completion between the mail survey and the telephone survey were categorized as "Inconsistent, but time factor may be involved", while respondents that reported implementation during the mail survey and no implementation during the telephone survey were categorized as "Inconsistent without explanation".

Table 2. Consistency of response determination matrix.

\begin{tabular}{l|cc}
\hline & \multicolumn{3}{|c}{ Telephone survey } & Did not Apply \\
\hline Applied & Applied & Inconsistent without explanation \\
Did not apply & Inconsistent but time factor may be involved & Consistent responses \\
\hline
\end{tabular}

\section{Limitations}

One major limitation encountered in this study was that three years had passed between the initial mail questionnaire and the telephone survey. The accuracy and consistency of responses could be questionable for this reason. As an attempt to address this issue, respondents were asked if they had added or reduced their property holdings since their enrollment in the program; for each forest management practice that had been applied as reported, respondents were asked to state the amount of time that had passed since practice implementation. In addition to these issues, non-response bias could not be examined due to the time between the surveys. It is understood that some of this bias exists within the data. Respondents may be more likely to apply management on their land than those who did not participate in this study. Finally, the definitions of each forest management practice that were provided to the telephone interviewers were basic to alleviate the occurrence of response bias due to the possibility of select participants wanting a formal explanation of forestry terms. This study relies on the assumption that information provided by these participants of the West Virginia FSP is truthful and accurate to the best of the respondents' knowledge. 


\section{CHAPTER IV}

\section{RESULTS}

\section{Response Rates and Participant Characteristics}

Of the 820 attempts to contact the top 54 percent of the randomly-generated list of telephone numbers, 327 interviews were completed, 383 were failed attempts due to no answer after three efforts or because of incorrect telephone numbers, and 110 refused to participate in the survey. Thirty-two surveys were completed, but due to duplicate survey identification numbers, these questionnaires were removed from analysis. This yielded a response rate of 36 percent. The cooperation rate, which represents interview completion when respondents were successfully contacted, was 67 percent.

There were 295 questionnaires completed during this telephone survey. Of the 295 completed interviews, 207 (70\%) respondents had participated in a previous mail survey of the West Virginia Forest Stewardship Program (Jennings, 2003). Respondents were asked if they had completed the mail questionnaire or if it had been completed by someone else in the household. One hundred ninety-one (65\%) reported that they were the primary participant of the previous study.

The average respondent was 67 years of age and had an average yearly income between $\$ 45,000$ and $\$ 60,000$. Men made up the majority (84\%) of respondents. Additionally, the majority of respondents were married (85\%). When asked about the highest level of education obtained, the largest proportion (28\%) of respondents had received a bachelor's degree. Sixtyeight percent of respondents reported having at least some college education.

The majority of respondents (87\%) stated that they had not added or reduced their property holding since enrolling in the Forest Stewardship Program (FSP) and inheritance (75\%) was the most common form of land acquisition. Fifteen percent of respondents had purchased their forestland, and a small proportion of respondents (9\%) reported both inheriting and purchasing their land. The duration of land ownership ranged from two to 204 years, while the average and median tenure was 25 years. Not all of the land owned by FSP participants is managed through the program. Acreage of holdings controlled by respondents totaled to 38,488 acres, of which 28,471 acres were reported to have a stewardship plan in place. The average 
property size was 195.4 acres, with FSP properties averaging 156 acres. Most respondents (77\%) reported owning only one property, but as many as five holdings were reported.

When asked if they considered their stewardship plan a useful tool to help implement forestry activities on their property, the majority of the respondents (86\%) stated that they felt it was useful $(n=276)$. Nearly one-third $(31 \%)$ referred to their plan once every couple of years or less (generally less than a yearly basis) (Table 3). Over two-thirds (69\%) reported that they reviewed their plan at least once a year. A small proportion of respondents (14\%) did not find their stewardship plan useful (Table 4). The most common reason reported for this was that they did not feel that the recommendations addressed their objectives (48\%). Although only nine participants (29\%) agreed with this statement, the next most often stated reason for lack of plan usefulness was that the respondents felt the recommendations were too vague.

Table 3. Respondents who felt their stewardship plan was useful were asked about the frequency that they referred to their plan $(n=238)$.

\begin{tabular}{lcc}
\hline & $\mathrm{n}$ & $\%$ \\
\hline Once every couple of years, or less & 68 & 31 \\
Once a year & 61 & 28 \\
Couple times a year & 65 & 30 \\
Once a month & 18 & 8 \\
More than once a month & 6 & 3 \\
\hline
\end{tabular}

Table 4. Respondents who did not feel their stewardship plan was useful were asked about the limitations of their plan $(\mathbf{n}=28)$.

\begin{tabular}{lcc}
\hline Recommendations do not address your objectives & $\mathrm{n}$ & $\%$ \\
Recommendations are too vague to be useful & 9 & 48 \\
Not sure how to carry out recommendations & 7 & 29 \\
No plan needed to manage your forestland & 7 & 24 \\
No time to carry out recommendations & 5 & 16 \\
Plan is missing or lost & 1 & 4 \\
\hline
\end{tabular}

Note: Percentages do not total to $100 \%$ due to multiple responses.

\section{Overall Practice Recommendation (Q 1.1,pg 22)}

Respondents were asked to report whether or not practices were recommended in their stewardship plans (Table 5). Of the practices that were suggested in respondents' management plans, timber harvesting was the most often reported (89\%). Grapevine control was suggested on over three-quarters $(79 \%)$ of the plans. Other practices that were recommended at least 50 percent of the time included timber stand improvement (65\%), water improvement (62\%), and 
wildlife habitat improvement (53\%). Improvement in appearance and soil protection were recommended on nearly half (47\%) of the survey participants' management plans. The least recommended practices were forest road construction (41\%) and tree planting (39\%).

Table 5. Frequency of practices recommended in the respondents' Stewardship plan.

\begin{tabular}{lcccc} 
& \multicolumn{2}{c}{ Recommended } & \multicolumn{2}{c}{ Not Recommended } \\
\cline { 2 - 5 } \multicolumn{1}{c}{ Practice } & $\mathrm{n}$ & $\%$ & $\mathrm{n}$ & $\%$ \\
\hline Timber harvest & 204 & 89 & 25 & 11 \\
Grapevine control & 173 & 79 & 45 & 21 \\
Timber stand improvement & 144 & 65 & 77 & 35 \\
Water improvement & 127 & 62 & 79 & 38 \\
Wildlife habitat improvement & 112 & 53 & 99 & 47 \\
Improvement in appearance & 92 & 47 & 102 & 53 \\
Soil protection & 93 & 47 & 106 & 53 \\
Forest road construction & 87 & 41 & 124 & 59 \\
Tree planting & 80 & 39 & 123 & 61 \\
\hline
\end{tabular}

\section{Implementation of Recommended Practices}

For respondents that reported the implementation of recommended practices on their property, the implementation rate, practice extent, and use of cost-share programs were examined (Table 6). Of those with timber stand improvement (TSI) recommended in their stewardships plan, two-thirds $(66 \%)$ had applied this practice in their forestlands. TSI application showed the third highest extent of practices implemented. The median application of TSI was 37 acres, totaling to 5,634 acres of enrolled property. Cost-share dollars were used by about one-quarter of respondents $(26 \%)$.

Table 6. Implementation of recommended practices. Percentages are based on the number of respondents that said a practice was recommended in their Stewardship plan.

\begin{tabular}{lcccccc} 
& \multicolumn{2}{c}{ Implemented } & \multicolumn{2}{c}{ Extent of Application } & \multicolumn{2}{c}{$\begin{array}{c}\text { Cost-share } \\
\text { funding used }\end{array}$} \\
\cline { 2 - 8 } \multicolumn{1}{c}{ Practice } & $\mathrm{n}$ & $\%$ & Median & Total & $\mathrm{n}$ & $\%$ \\
\hline Timber stand improvement & 95 & 66 & $37 \mathrm{ac}$ & $5,634 \mathrm{ac}$ & 25 & 26 \\
Soil protection & 60 & 64 & $30 \mathrm{ac}$ & $3,071 \mathrm{ac}$ & 9 & 15 \\
Improvement in appearance & 55 & 60 & $32 \mathrm{ac}$ & $6,737 \mathrm{ac}$ & 8 & 14 \\
Timber harvest & 120 & 59 & $47 \mathrm{ac}$ & $10,340 \mathrm{ac}$ & $\mathrm{n} / \mathrm{a}$ & $\mathrm{n} / \mathrm{a}$ \\
Wildlife habitat improvement & 59 & 53 & $40 \mathrm{ac}$ & $4,204 \mathrm{ac}$ & 7 & 12 \\
Grapevine control & 84 & 49 & $20 \mathrm{ac}$ & $3,714 \mathrm{ac}$ & 19 & 23 \\
Tree planting & 33 & 41 & $5 \mathrm{ac}$ & $327 \mathrm{ac}$ & 11 & 33 \\
Forest road construction & 26 & 30 & $2 \mathrm{mi}$ & $44 \mathrm{mi}$ & 5 & 19 \\
Water improvement & 36 & 28 & $4 \mathrm{ac}$ & $451 \mathrm{ac}$ & 7 & 19 \\
\hline
\end{tabular}


Nearly two-thirds of respondents $(64 \%)$ that had soil protection suggested by their plan writer reported on-the-ground implementation (Table 6). Covering slightly more than 3,000 acres of these private forestlands, the median implementation of soil protection was 30 acres. Nine of the 60 respondents $(15.0 \%)$ that applied soil protection on their forestlands achieved implementation through the assistance of cost-share funds.

Improvement in appearance and timber harvesting was implemented nearly 60 percent of the time it was recommended, with a median of 32 acres and 47 acres, respectively (Table 6). The application of improving the appearance of forestlands as recommended in the Stewardship plan was implemented using cost-share assistance by 14 percent of respondents. Improvement in appearance was employed on the second largest total coverage of nearly 7,000 acres. Timber harvests encompassed the greatest land application, totaling to over 10,000 acres of FSP lands.

Slightly more than half (52.9\%) of respondents stating that wildlife habitat improvement was suggested in their plan had applied such practices on their land (Table 6). The median application of wildlife habitat improvement was 40 acres, and total application on FSP lands was over 4,200 acres. Only 12 percent of respondents applied recommended wildlife habitat improvement through cost-share programs. Six of the seven respondents that used cost-share funding also reported that they were members of the Wildlife Habitat Improvement Program (WHIP), which aids private forestland owners in implementing such practices on their land (not shown in table).

Just below 50 percent of recommended grapevine control (49\%) was applied (Table 6). The total acreage treated for grapevine control encompassed 3,714 acres with a median of 37 acres per application. Over two-fifths of these respondents (23\%) reported using cost-share dollars to implement grapevine control. Tree planting was implemented 41 percent of the time it was recommended and also had median of 5 acres planted per application and 327 acres of total plantings on FSP enrolled lands. Of the practices that were applied as recommended, tree planting occurred more often in conjunction with cost-share funding than any other practice. One-third of respondents (33\%) stated that they had used cost-share dollars to plant trees.

Suggestions for forest road construction were followed about 30 percent of the time. The median forest road built was 2 miles and a total of 44 miles of roads were built on these FSP lands (Table 6). Only five (19\%) of respondents that built recommended forest roads did so through cost-share programs. Water improvement was put into action as suggested through the 
respondents' Stewardship plan over one-quarter (28\%) of the time. The median application of water improvement was 4 acres, totaling to 451 acres. Through the use of cost-share funding, 19 percent of respondents applied recommended water improvement practices.

\section{Associations and Correlations between Recommended and Implemented Practices}

Crosstabs and Pearson's chi-square statistics examined the relationship between practice recommendation and practice implementation. Only two practices proved a significant relationship between these variables $(\alpha<0.05)$. Timber stand improvement (TSI) application was associated $\left(p<0.001, \chi^{2}=13.411, d f=1\right)$ with recommendation (Table 7$)$. The majority ( $83 \%$ ) of respondents that reported this practice was suggested in their stewardship plan had also reported implementation and over two-thirds (69\%) that did not have TSI recommended reported no application. Crosstabs and Pearson's chi-square statistics showed a significant association $\left(p=0.001, \chi^{2}=11.296, d f=1\right)$ between soil protection recommendation and implementation. Twothirds of respondents $(67 \%)$ that had not implemented soil protection reported that such practices were not recommended in their stewardship plan. Although a more subtle difference, a larger proportion $(58 \%)$ reported implementation with practice recommendation than those that reported implementation without recommendation (42\%).

Table 7. Cross tabulation of the significant association between practice recommendation and forestry practice application.

\begin{tabular}{|c|c|c|c|c|c|}
\hline & \multirow[b]{2}{*}{ Recommended } & & \multicolumn{2}{|c|}{ Practice Applied } & \multirow[b]{2}{*}{ Total } \\
\hline & & & No & Yes & \\
\hline \multirow[t]{6}{*}{ Timber stand improvement } & No & Count & 36 & 29 & 65 \\
\hline & & $\%$ & 49 & 23 & 33 \\
\hline & Yes & Count & 38 & 95 & 133 \\
\hline & & $\%$ & 51 & 77 & 67 \\
\hline & Total & Count & 74 & 124 & 198 \\
\hline & & $\%$ & 100 & 100 & 100 \\
\hline \multirow[t]{6}{*}{ Soil protection } & No & Count & 58 & 44 & 102 \\
\hline & & $\%$ & 67 & 42 & 53 \\
\hline & Yes & Count & 29 & 60 & 89 \\
\hline & & $\%$ & 33 & 58 & 47 \\
\hline & Total & Count & 87 & 104 & 191 \\
\hline & & $\%$ & 100 & 100 & 100 \\
\hline
\end{tabular}




\section{Influence of Practice Recommendation on Extent of Implementation}

Independent t-tests were used to test whether there were significant differences in extent of each practice application when recommended or not recommended. Regardless of practice recommendation in the respondents' stewardship plan, the average extent of implementation did not differ substantially for any of the practices.

Overall Practice Implementation (Q 1.2, pg 22)

The number of practices implemented on these lands regardless of practice recommendation ranged from zero to 10 . Only four percent $(n=13)$ of all respondents indicated that they had not applied any of the practices surveyed. On average, respondents had implemented four practices on their land.

Respondents were asked if they had applied forest management practices. When the respondents had implemented management practices, they were also asked to report the acreage to which it was applied and if cost-share dollars were used (Table 8). Timber harvesting represented the most frequently implemented practice (55\%), regardless of recommendation. The median harvested area was 40 acres, totaling to 12,502 acres among all participants. Timber stand improvement (TSI) was also highly implemented, as over one-half of respondents (54\%) reported applying this practice. The median extent of application was 36 acres, and all reported TSI applications totaled to 8,682 acres. Only one-fifth (21\%) of those who reported implementation of TSI had used cost-share funds to do so. This practice, however, had the largest number of respondents that used these funds.

Table 8. Implementation of, coverage, and cost-share use for forest management practices.

\begin{tabular}{lcccccc}
\hline & \multicolumn{2}{c}{ Implemented } & \multicolumn{2}{c}{ Application Coverage } & \multicolumn{2}{c}{ Cost-share funding used } \\
\cline { 2 - 7 } \multicolumn{1}{c}{ Practice } & $\mathrm{n}$ & $\%$ & Median & Total & $\mathrm{n}$ & $\%$ \\
\hline Timber harvest & 161 & 55 & $40 \mathrm{ac}$ & $12,502 \mathrm{ac}$ & $\mathrm{n} / \mathrm{a}$ & $\mathrm{n} / \mathrm{a}$ \\
Timber stand improvement & 158 & 54 & $36 \mathrm{ac}$ & $8,682 \mathrm{ac}$ & 34 & 21 \\
Improvement in appearance & 158 & 54 & $50 \mathrm{ac}$ & $16,621 \mathrm{ac}$ & 18 & 11 \\
Soil protection & 148 & 50 & $25 \mathrm{ac}$ & $6,795 \mathrm{ac}$ & 23 & 15 \\
Wildlife habitat improvement & 140 & 47 & $40 \mathrm{ac}$ & $12,175 \mathrm{ac}$ & 14 & 10 \\
Grapevine control & 131 & 44 & $20 \mathrm{ac}$ & $5,095 \mathrm{ac}$ & 29 & 22 \\
Tree planting & 105 & 36 & $4 \mathrm{ac}$ & $837 \mathrm{ac}$ & 27 & 26 \\
Recreational opportunities & 98 & 33 & $50 \mathrm{ac}$ & $8,530 \mathrm{ac}$ & 7 & 7 \\
Forest road construction & 81 & 27 & $2 \mathrm{mi}$ & $117 \mathrm{mi}$ & 10 & 12 \\
Water improvement & 69 & 23 & $4 \mathrm{ac}$ & $1,399 \mathrm{ac}$ & 19 & 28 \\
\hline
\end{tabular}


Over one-half $(53 \%)$ of the respondents had implemented practices to improve the appearance or aesthetics of their forestlands (Table 8). Improvements to forestland appearance represented a median of 50 acres per application and the highest total (16,621 acres) extent of application among all practices. Only 11 percent of the respondents that had applied such practices used cost-share funds. Soil protection was implemented by one-half (50\%) of survey participants. Soil loss and erosion control practices showed a median application of 25 acres and total application on these properties was nearly 6,800 acres. Cost-share dollars supported only 15 percent of soil protection.

Wildlife habitat improvement occurred on less than one-half of these properties (47\%), but was applied to a total of 12,175 acres (Table 8). The median application of wildlife habitat improvement was 40 acres. Ten percent of respondents reported that cost-share programs were used to help cover the costs of practice application. Eleven of the 14 respondents that reported using cost-share funds for wildlife habitat improvement also reported that they had used funding from the Wildlife Habitat Improvement Program (WHIP). Grapevine control was applied to over 5,000 acres of FSP lands surveyed in this study. Just over two-fifths (44\%) of respondents had applied grapevine control on their properties, and the median extent of application was 20 acres. Nearly one-quarter of respondents $(22.1 \%)$ that reported grapevine control applied the practice with the help of cost-share programs.

Tree planting and the development of recreational opportunities were implemented on approximately one-third of properties (36\% and 33\%, respectively) involved in this study (Table 8). The median acreage planted was 4 acres, and total plantings accounted for 837 acres of these FSP enrolled properties. Slightly over one-quarter of respondents $(26 \%)$ that had planted trees reported using cost-share programs to fund this practice. Sharing the highest median of practice application (50 acres) with improvements in appearance, the development of recreational opportunities was carried out on a total of 8,426 acres. The lowest number of respondents stated that they had used cost-share funds to implement this practice, with only seven percent of those that had applied recreation development reporting that they had used cost-share programs.

The two least often applied practices were forest road construction and water improvement (Table 8). Over one-quarter of respondents $(27 \%)$ that reported road construction, but, only 12 percent of them used cost-share fund to implement this practice. The median length of forest roads that were built was 2 miles. Respondents reported constructing a total of 117 
miles of road on their properties. Water improvement was applied to only 23 percent of surveyed properties. Proportionately, more respondents used cost-share dollars to implement this practice than any of the practices. Just over one-quarter (28\%) of those implementing water improvement did so through the assistance of cost-share programs. The median application of this practice was 4 acres, totaling to nearly 1,400 acres on Forest Stewardship properties.

\section{Correlation between the Extents of Practice Implementation}

Based on the extent of practice application (acres/miles), Pearson's correlation was used to test the relationships among practices (Table 9). All significant relationships found through this analysis were positively correlated. The extent of timber harvesting proved significantly correlated with timber stand improvement (TSI) $(r=0.32)$, grapevine control $(r=0.41)$, wildlife habitat improvement ( $r=0.47)$, forest road construction $(r=0.63)$, soil protection $(r=0.25)$, improvement in appearance ( $r=0.42)$, and recreation development $(r=0.48)$.

The amount of acreage on which TSI was applied was significantly related to the extent of grapevine control ( $r=0.73)$, wildlife habitat improvement $(r=0.53)$, soil protection $(r=0.51)$, improvement in appearance $(r=0.59)$, and recreation development $(r=0.54)$. There was also significant relationship between the extent of grapevine control and wildlife habitat improvement ( $r=0.54)$, forest road construction $(r=0.66)$, tree planting $(r=0.47)$, improvement in appearance $(r=0.67)$, and recreation development $(r=0.78)$. The coverage of wildlife habitat improvement was associated with miles of forest road construction $(r=0.77)$, acres of soil protection $(r=0.31)$, improvement in appearance $(r=0.84)$, and recreation development $(r=0.53)$. The extent of forest road construction was significantly correlated with the extent of improvement in appearance $(r=0.46)$. Acres on which soil protection was applied proved significantly related to the extent of improvement in appearance $(r=0.47)$ and recreation development $(r=0.46)$. The extent of improvement in appearance was correlated with the extent of recreation development $(r=0.79)$. 
Table 9. Pearson correlation coefficients between the extents of practice implementation. All practices were recorded as the number of acres that had been treated with a specific practice except forest road construction (recorded in miles).

\begin{tabular}{|c|c|c|c|c|c|c|c|c|c|c|}
\hline Practice & $\begin{array}{l}\text { Timber } \\
\text { harvest }\end{array}$ & TSI & $\begin{array}{l}\text { Grapevine } \\
\text { control }\end{array}$ & $\begin{array}{c}\text { Wildlife } \\
\text { habitat } \\
\text { improvement }\end{array}$ & $\begin{array}{l}\text { Forest road } \\
\text { construction }\end{array}$ & $\begin{array}{c}\text { Tree } \\
\text { planting }\end{array}$ & $\begin{array}{c}\text { Water } \\
\text { improvement }\end{array}$ & $\begin{array}{c}\text { Soil } \\
\text { protection }\end{array}$ & $\begin{array}{l}\text { Improvement } \\
\text { in appearance }\end{array}$ & $\begin{array}{c}\text { Recreation } \\
\text { development }\end{array}$ \\
\hline Timber harvest & & $0.32 * *$ & $0.41 * *$ & $0.47 * * *$ & $0.63 * * *$ & 0.14 & 0.02 & $0.25 *$ & $0.42 * *$ & $0.48 * *$ \\
\hline TSI & & & $0.73 * * *$ & $0.53 * * *$ & 0.03 & 0.10 & 0.03 & $0.51 * * *$ & $0.59 * * *$ & $0.54 * *$ \\
\hline Grape vine control & & & & $0.54 * * *$ & $0.66 * *$ & $0.47 *$ & 0.22 & 0.01 & $0.67 * * *$ & $0.78^{* *}$ \\
\hline Wildlife habitat improvement & & & & & $0.77^{* * *}$ & -0.02 & -0.09 & $0.31 * *$ & $0.84 * * *$ & $0.53 * *$ \\
\hline Forest road construction & & & & & & -0.06 & 0.43 & 0.06 & $0.46^{*}$ & 0.33 \\
\hline Tree planting & & & & & & & -0.15 & 0.06 & 0.00 & 0.09 \\
\hline Water improvement & & & & & & & & 0.16 & 0.32 & -0.03 \\
\hline Soil protection & & & & & & & & & $0.47 * * *$ & $0.46^{* *}$ \\
\hline Improvement in appearance & & & & & & & & & & $0.79 * * *$ \\
\hline
\end{tabular}

$* p<0.05$. ** $p<0.01$. *** $p<0.001$. 


\section{Additional Information about Practice Implementation}

Respondents were asked about factors that may have influenced their decision to apply forest management on their land (Table 10). The most common reason that management practices were implemented on these FSP properties was for the purpose of conserving resources, with the majority of respondents (83\%) agreeing with this statement. In addition, a large proportion of respondents $(63 \%)$ stated that their reason for implementing practices was income, or that harvesting provided additional income. The existence of cost-share programs was the reason for implementation by nearly two-fifths $(38 \%)$ of respondents. The least common factors that encouraged practice application were the influence of friends or neighbors $(23 \%)$ and timber harvesting being used as primary income (18\%).

Table 10. Reasons for implementing forest management practices. Respondents were asked if any of the following were strong motivating reasons for implementing any of the management practices on their land.

\begin{tabular}{lcc}
\hline & $\mathrm{n}$ & $\%$ \\
\hline Conservation of resources & 230 & 83 \\
I needed the income/Harvesting is additional income & 171 & 63 \\
Cost-share programs & 103 & 38 \\
Influence of friends or neighbors & 61 & 23 \\
Timber harvesting is primary income & 51 & 18 \\
\hline
\end{tabular}

Note: Percentages do not total to $100 \%$ due to multiple responses.

When respondents reported that they had applied a specific practice, they were also asked about the length of time that had passed since they had implemented that practice (Figure 1). Nearly one-half of the respondents stated that they had applied grapevine control (47\%) and soil protection (45\%) between 2003 and 2005. Just over two-fifths of respondents (42\%) implemented practices to improve the appearance of their land during the same period. Only about one-quarter of these practices were applied before 2000.

Most applied TSI practices (36.2\%) occurred between 2000 and 2002 (Figure 1). Between 2000 and 2005, nearly two-thirds of the reported of TSI implementation (64\%) was applied. Similarly, around two-thirds of recreational development (66\%), wildlife habitat improvement (65\%), and tree planting (64\%) occurred during this time frame. Water improvement practices were implemented with equal distribution through time, but more application (33\%) was reported between 2003 and 2005 (Figure 1). This trend was also evident 
with timber harvesting. Forest road construction occurred at nearly equal distribution through time, but more road establishment was reported to occur prior to 1995.

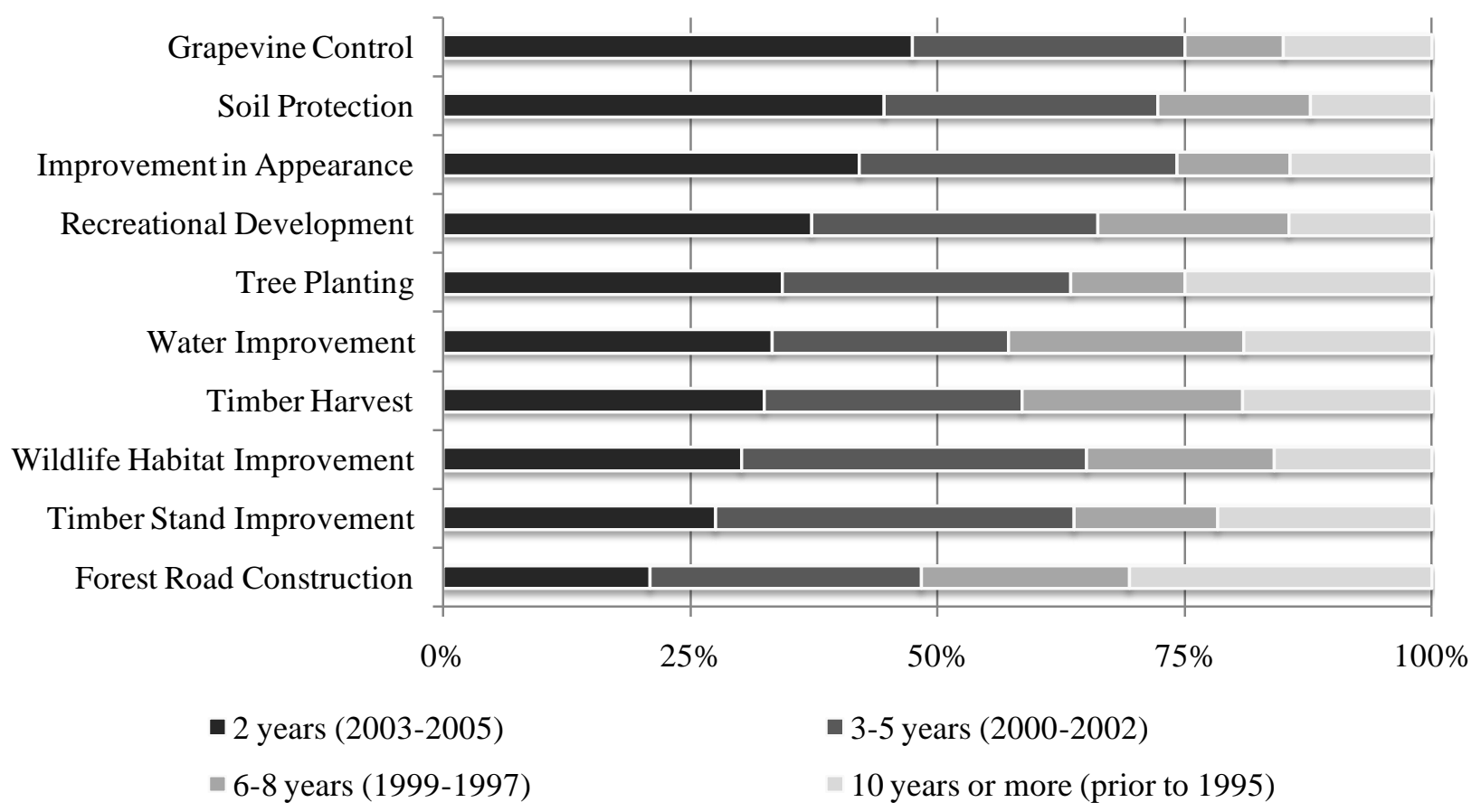

Figure 1. Time that has passed since the forest management practice was applied. Percentages are based on the number of respondents that stated the practice had been implemented and reported a time frame in which the practice was completed. 
Respondents were asked to state their challenges that prevented them from carrying out each of the management practices in question (Table 11). The primary constraint for many respondents was the lack of time to implement various practices. This was the most often cited reason of not following through with the application of timber stand improvement (TSI), improvement in appearance, soil protection, tree planting, wildlife habitat improvement, the development of recreational opportunities, and forest road construction. The main challenge that kept respondents from implementing timber harvesting, grapevine control, and water improvement was unsuitable conditions to perform management practice.

Table 11. Reasons for failure to implement forest management practices. When a respondent stated that a practice was not implemented, they were asked if they did not apply the practice due to 1) lack of time 2) monetary restrictions 3) unsuitable conditions. Although responses were not exclusive, the most often reported constraint is reported here, with percentages based on the number of responses expressing that a practice was not implemented.

\begin{tabular}{llcc}
\hline & Practice & $\mathrm{n}$ & $\%$ \\
\hline Takes too Much Time & & & \\
\hline & Timber stand improvement & 23 & 26 \\
& Improvement in appearance & 28 & 23 \\
& Soil protection & 23 & 18 \\
& Tree planting & 29 & 18 \\
& Wildlife habitat improvement & 10 & 14 \\
& Recreational opportunities & 20 & 13 \\
& Forest road construction & 15 & 9 \\
\hline Unsuitable conditions & & & \\
\hline & Timber harvest & 48 & 43 \\
& Grapevine control & 49 & 41 \\
& Water improvement & 23 & 12 \\
\hline
\end{tabular}

\section{Supplemental Questions for Select Practices}

\section{Timber Harvest}

Respondents were also asked about important details pertaining to their timber harvesting experience. Out of 154 responses, over two-thirds (68\%) of the respondents reported that a forester was involved with their timber harvest. The purposes of timber harvest varied greatly and many respondents reported multiple reasons (Table 12). The most often cited purpose of timber harvesting (90\%) was that the timber on their land was mature or over mature. Other reasons were that the harvest was recommended in their Forest Stewardship Plan (74\%) or that 
they wanted income from their timberlands (66\%). Diseased or damaged trees explained harvesting practices of over one-half (54\%) of respondents.

Table 12. Purpose of timber harvest. Respondents were asked which statement described the reasons for their harvest.

\begin{tabular}{lcc}
\hline & $\mathrm{n}$ & $\%$ \\
\hline Mature or over-mature timber & 121 & 90 \\
Recommended in the Forest Stewardship Plan & 99 & 74 \\
Income & 92 & 66 \\
Diseased or damaged trees & 69 & 54 \\
Insect infestation & 31 & 25 \\
Conversion--pasture/plantation & 8 & 5 \\
\hline
\end{tabular}

Note: Percentages do not total to 100 percent due to multiple responses.

Of the 31 respondents (20\% of responses) that reported additional harvest over the past years, the median acreage harvested was 50 acres. Collectively, they reported 1,378 acres of FSP enrolled property had been harvested within the past 10 years in addition to the most recent.

\section{Timber Stand Improvement}

The only additional question asked about the respondents' application of a timber stand improvement was if the practice involved any thinning activities. Over two-thirds $(68 \%)$ reported that thinning activities were carried out in conjunction with TSI implementation.

\section{Grapevine Control}

Over one-half of respondents (53\%) reported that a vegetation inventory had been completed to determine the extent of grapevine problems on their property prior to grapevine control implementation. Physical methods of control were by far the most common of practice application. Ninety-eight percent of respondents used physical methods to control grapevine on their property. Although three respondents $(2 \%)$ stated that they had used both chemical and physical methods, no one reported that chemical methods as their only method to control grapevine.

\section{Forest Road Construction}

Respondents were also asked about road construction details. Respondents reported that out-sloped or crowned roads were built in over one-half (59\%) of the road construction projects. 
Drainage dips were built on nearly two-thirds (64\%) of reported forest road construction practices. Similarly, in-sloped roads, ditches, and cross drains were built in slightly less than two-thirds of reported practices $(63 \%)$.

\section{Recreational Opportunities}

Respondents were asked about public or personal use of their forestland property. The majority (93\%) reported that their land was only open for personal use, while a small number of respondents (5\%) said that is was open to both personal and public use. When asked about the potential recreational opportunities that participants may have on their forestlands, hunting $(93 \%)$ and hiking $(81 \%)$ were the highest reported activities (Table 13). Other possible opportunities were camping (56\%), biking (38\%), and fishing (34\%). Similarly, hunting and hiking were the most often reported activities that were carried out, representing around threequarters of respondents. Less than one third (30\%) of respondents reported camping on their forestland. One-quarter of respondents fished on their property.

Table 13. Recreational opportunities that are possible or carried out.

\begin{tabular}{lcccc}
\hline & \multicolumn{2}{c}{ Potential } & Activities & \multicolumn{2}{c}{ Existing Activities } \\
\cline { 2 - 5 } & $\mathrm{n}$ & $\%$ & $\mathrm{n}$ & $\%$ \\
\hline Hunting & 253 & 93 & 209 & 76 \\
Hiking & 211 & 81 & 187 & 71 \\
Camping & 142 & 56 & 79 & 30 \\
Biking & 95 & 38 & 42 & 16 \\
Fishing & 87 & 34 & 66 & 25 \\
Skiing & 37 & 15 & 25 & 9 \\
Rock Climbing & 26 & 10 & 16 & 6 \\
Whitewater Rafting & 6 & 2 & 4 & 2 \\
\hline Note: Percentages do not total to & 100\% due to & multiple responses.
\end{tabular}


Land Ownership Objectives ( $Q 1.3$, pg 22)

Respondents were asked to rate on a 4-point scale how important they viewed various land ownership objectives (Table 14). Very important and somewhat important ratings were combined, as were responses that an objective was somewhat unimportant and not at all important. The most often reported objective was maintaining and improving investment value, which was important to 94 percent of respondents. Ninety percent of respondents felt that creating wildlife habitat, preventing soil loss and erosion, and maintaining/improving appearance were important land ownership objectives. Maintaining and improving water quality was seen as important by over three-quarters of respondents (83\%). Three-quarters of respondents stated that providing for recreation was important. Although nearly two-thirds (62\%) reported that providing supplemental income was very or somewhat important, this objective was the second least important goal of ownership. The objective of generating primary income was overall of least importance, with less than two-fifths of respondents (39\%) reporting it as important.

Table 14. Importance of Land Ownership Objectives. Respondents were asked whether they felt a specific objective was 'Very important', 'Somewhat important', 'Somewhat unimportant' or 'Not at all important'. Very important and somewhat important were combined as important. Somewhat unimportant and not at all important were combined as not important.

\begin{tabular}{lcccc}
\hline \multirow{2}{*}{ Objective } & \multicolumn{2}{c}{ Important } & \multicolumn{2}{c}{ Not Important } \\
\cline { 2 - 5 } & $\mathrm{n}$ & $\%$ & $\mathrm{n}$ & $\%$ \\
\hline Maintain and improve investment value & 255 & 94 & 15 & 6 \\
Create wildlife habitat & 238 & 90 & 25 & 9 \\
Prevent soil loss and erosion & 223 & 90 & 24 & 10 \\
Maintain and improve appearance & 231 & 90 & 25 & 10 \\
Maintain and improve water quality & 216 & 83 & 44 & 17 \\
Provide for recreation & 192 & 76 & 62 & 24 \\
Provide supplemental income & 157 & 62 & 98 & 38 \\
Generate primary income & 97 & 39 & 150 & 61 \\
\hline
\end{tabular}


Respondents were also asked to report which of the land ownership objectives were most important and next most important for their land management (Table 15). The five most important or the second most important land ownership objective was 1) creating wildlife habitat (46\%), 2) maintaining and improving investment value (41\%), and 3) preventing soil loss and erosion (37\%). Less than one-fifth of survey participants reported maintaining and improving appearance as their most or next most important objective. The lowest number of respondents expressed that providing supplemental income and generating primary income was an important land ownership objective, representing 11 and nine percent of responses, respectively.

\section{Table 15. Responses on which land ownership objectives are 'Most' or 'Next most'} important. In addition to rating each objective, respondents were asked to single out their most and next most important land ownership objective. The total responses and percentages represent the sum of responses that the objective was most or next most important to the respondent.

\begin{tabular}{lcccccc}
\hline & \multicolumn{2}{c}{ Most Important } & Next Most Important & \multicolumn{2}{c}{ Total } \\
\cline { 2 - 7 } Objective & $\mathrm{n}$ & $\%$ & $\mathrm{n}$ & $\%$ & $\mathrm{n}$ & $\%$ \\
\hline Create wildlife habitat & 66 & 26 & 44 & 20 & 110 & 46 \\
Maintain and improve investment value & 75 & 29 & 26 & 12 & 101 & 41 \\
Prevent soil loss and erosion & 43 & 17 & 45 & 20 & 88 & 37 \\
Maintain and improve water quality & 24 & 9 & 24 & 11 & 48 & 20 \\
Provide for recreation & 15 & 6 & 32 & 14 & 47 & 20 \\
Maintain and improve appearance & 9 & 3 & 23 & 10 & 32 & 14 \\
Provide supplemental income & 13 & 5 & 13 & 6 & 26 & 11 \\
Generate primary income & 9 & 3 & 14 & 6 & 23 & 10 \\
\hline
\end{tabular}

Note: Percentages do not total to $100 \%$ due to multiple responses.

\section{Land Ownership Objectives related to Recommended and Implemented Practices}

Frequencies of recommended and implemented practices were evaluated for land ownership objectives that were cited as most or next most important to survey participants. The number and percentage of responses in which respondents stated that the objective was most or next most important were combined to facilitate analysis. Only the top three most often reported objectives were evaluated because less than one-third of responses were associated with other objectives (Table 15).

Creating wildlife habitat was viewed as one of the most important objectives by the largest number of respondents $(n=110)$ (Table 16). The two most recommended practices for respondents reporting wildlife habitat as the most and next most important objective were timber 
harvesting (75\%) and grapevine control (74\%). These practices were applied at lower rates, with 48 percent of respondents harvesting timber and 40 percent controlling grapevine. The next most recommended practice was timber stand improvement (TSI), which was suggested on 54 percent of these plans. TSI was one of the most often applied practices for respondents placing high importance on creating wildlife habitat. It was reported with slightly higher numbers of implementation than recommendations at 58 percent of respondents applying this practice.

Table 16. Recommended and applied practice (percent) by the objectives of most or next most importance among respondents. Data were not available for the recommendation of recreation development.

\begin{tabular}{|c|c|c|c|c|c|c|}
\hline & \multicolumn{2}{|c|}{$\begin{array}{l}\text { Create wildlife habitat } \\
\qquad(\mathrm{n}=110)\end{array}$} & \multicolumn{2}{|c|}{$\begin{array}{l}\text { Maintain and } \\
\text { improve value } \\
\quad(n=101)\end{array}$} & \multicolumn{2}{|c|}{$\begin{array}{c}\text { Prevent soil } \\
\text { loss and erosion }(n=88)\end{array}$} \\
\hline & Recommended & Applied & Recommended & Applied & Recommended & Applied \\
\hline Timber Harvest & 75 & 48 & 70 & 52 & 69 & 51 \\
\hline Grapevine Control & 75 & 40 & 59 & 50 & 56 & 51 \\
\hline Timber Stand Improvement & 55 & 58 & 54 & 59 & 49 & 51 \\
\hline Water Improvement & 48 & 22 & 41 & 24 & 45 & 23 \\
\hline Improvement in Appearance & 42 & 42 & 29 & 29 & 31 & 31 \\
\hline Wildlife Habitat Improvement & 41 & 40 & 47 & 50 & 32 & 51 \\
\hline Soil Protection & 35 & 54 & 25 & 45 & 30 & 56 \\
\hline Forest Road Construction & 34 & 58 & 24 & 46 & 28 & 41 \\
\hline Tree Planting & 27 & 35 & 32 & 32 & 27 & 38 \\
\hline Recreational Opportunities & -- & 39 & -- & 29 & -- & 20 \\
\hline
\end{tabular}

Of respondents that cited creating wildlife habitat a top objective, over half (58\%) had constructed forest roads (Table 16). Only one-third (34\%) of respondents acknowledged that this practice was recommended in their stewardship plan. Soil protection was also a substantially applied practice, with over one-half (54\%) of respondents stating that it had been implemented on their land. Just over one-third of respondents (35\%) reported that soil protection had been recommended in their plan. Only two-fifths (41\%) of respondents had wildlife habitat improvement practices recommended in their plan, and nearly the same percent of respondents (40\%) stated that they had applied such practices on their land.

The second highest reported landownership objective referenced to as the most or next most important was maintaining and improving investment value (Table 16). As with the previous objective, the number of times that practices were recommended and applied was 
examined. Timber harvesting (70\%) and grapevine control (55\%) were the most often recommended practices. In terms of application, these practices were applied by around one-half (52\% and 49\%, respectively) of survey participants. Timber stand improvement (TSI) (54\%) and wildlife habitat improvement (46\%) followed in the number of plans recommending these practices. TSI was the most often applied practice, with nearly two-thirds of respondents (59\%) citing its implementation. Wildlife habitat improvement was applied by just about one-half of the respondents (49\%). Shown as the two least often recommended practices, soil protection and forest road construction were applied by a relatively high number of respondents, ranging between 44 and 46 percent of participants. Tree planting and improving the forestland's appearance were recommended the same number of times these practices were implemented, at 29 percent and 32 percent, respectively.

Preventing soil loss and erosion was cited as the third most important landownership objective (Table 16). The most recommended practices in management plans written for respondents were timber harvesting (69\%) and grapevine control (56\%). These practices, as well as timber stand improvement (TSI) and wildlife habitat improvement were applied by just over one-half of respondents (53\%). TSI and wildlife habitat improvement were applied more often than recommended through the respondents' stewardship plan. The most often applied practice was soil protection, with respondents reporting implementation on 56 percent of surveyed FSP properties. Application of forest road construction and tree planting were reported more often than they were recommended, with about two-fifths of respondents (37\% and $41 \%$, respectively) reporting implementation.

\section{Landownership Objectives and Extent of Practice Application}

Analysis of variance (ANOVA) was used to find relationships between extents of practice application in terms of the landowners' most important ownership objective. No significant differences were found between the objective groups in terms of the extent of timber harvesting, grapevine control, forest road construction, tree planting, water improvement, soil protection, and improvement in appearance. The means and standard deviations for these practices were very similar, showing that the objective groups had little or no influence on the extent of practice application (Table 17). 
Table 17. Summary data and Analysis of Variance: Extent of practice implementation (original values) by land ownership objectives. Objective Group 1 includes maintain/improve investment value, generate primary income, and provide supplemental income. Objective group 2 includes create wildlife habitat, develop recreational opportunities, and maintain/improve appearance. Objective group 3 includes prevent soil loss and erosion, and maintain/improve water supply.

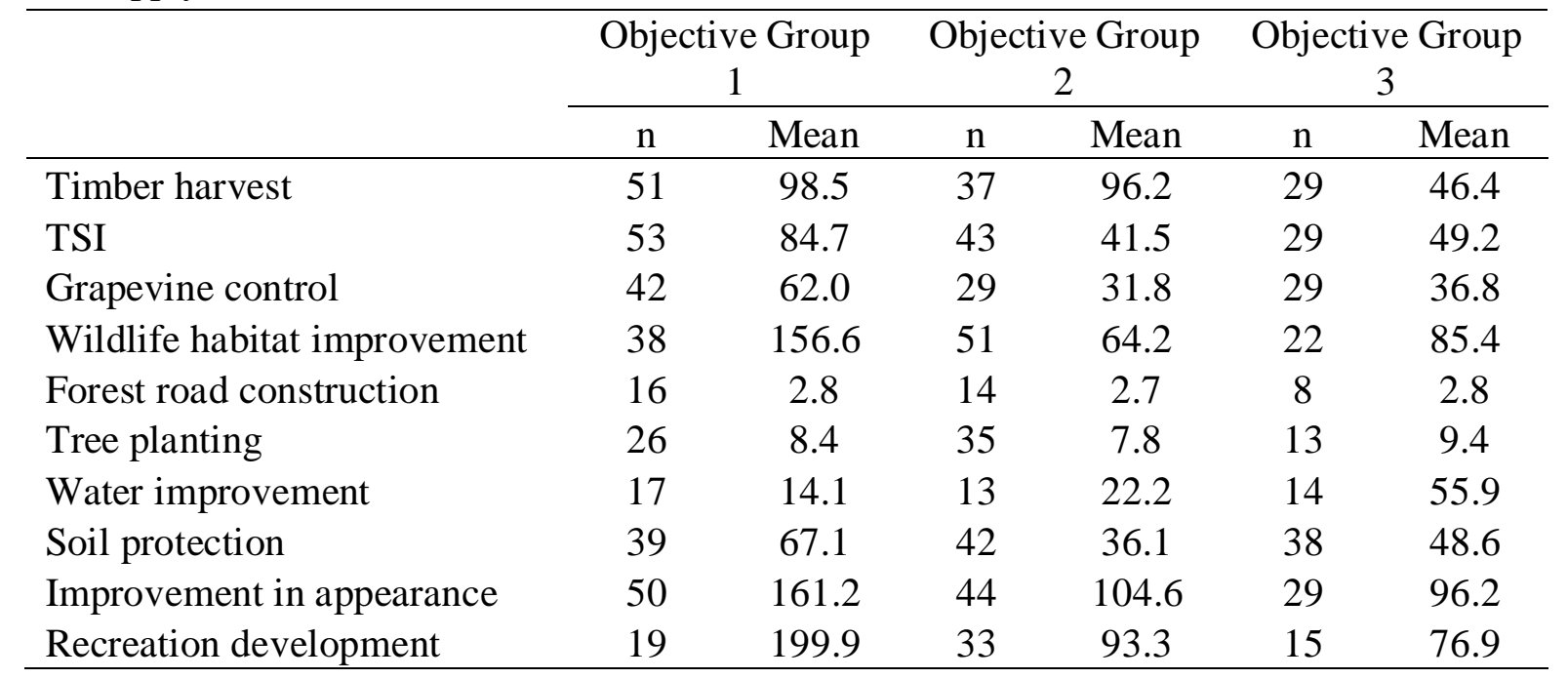


There were, however, significant differences found between the groups $(\alpha=0.05)$ with respect to the application extent of timber stand improvement (TSI), wildlife habitat improvement, and recreation development (Table 18). Bonferroni post hoc analysis revealed that respondents in Objective Group 1 implemented TSI to a greater extent than Group 2 (Table 19). In addition, Objective Group 1 implemented more wildlife habitat improvement than both Group 1 and 2. Recreation development practices were implemented on a larger extent by respondents who felt the objectives in Group 1 were most important than those in Group 3.

Table 18. Analysis of Variance: Extent of practice application by Objective Groups.

\begin{tabular}{llcccc}
\hline & & $S S$ & $d f$ & $M S$ & $F$ \\
\hline Timber stand improvement & Between Groups & 8.11 & 2 & 4.05 & $3.07^{*}$ \\
& Within Groups & 161.04 & 122 & 1.32 & \\
& Total & 169.15 & 124 & & \\
\hline Wildlife habitat improvement & Between Groups & 48.99 & 2 & 24.50 & $11.76^{* *}$ \\
& Within Groups & 224.92 & 108 & 2.08 & \\
& Total & 273.91 & 110 & & \\
\hline Recreation development & Between Groups & 24.12 & 2 & 12.06 & $4.04^{*}$ \\
& Within Groups & 191.08 & 64 & 2.99 & \\
& Total & 215.20 & 66 & & \\
\hline
\end{tabular}

$* p<0.05 . * * p<0.001$

Table 19. Analysis of Variance: Bonferroni post hoc analysis of significantly different objective groups in terms of extent of practice implementation.

\begin{tabular}{lcccc} 
Dependent Variable & $\begin{array}{c}\text { (I) Objective } \\
\text { Group }\end{array}$ & $\begin{array}{c}\text { (J) Objective } \\
\text { Group }\end{array}$ & $\begin{array}{c}\text { Mean Difference } \\
(\mathrm{I}-\mathrm{J})\end{array}$ & SE \\
\hline Timber stand improvement & 1 & 2 & $0.58^{*}$ & 0.24 \\
\hline Wildlife habitat improvement & 1 & 2 & $1.48^{* *}$ & 0.31 \\
& & 3 & $1.11^{*}$ & 0.39 \\
\hline Recreation development & 1 & 3 & $1.60^{*}$ & 0.60 \\
\hline
\end{tabular}

$* p<0.05 . * * p<0.001$ 
The Use of Cost-share Programs ( $Q 1.4, p g$ 22)

The number of times these individuals utilized cost-share programs for practice implementation ranged from zero to seven times, but most (55\%) of respondents reported costshare assistance on only one occasion. Due to limited numbers of respondents using cost-share programs, this portion of the analysis was limited to four practices, which had at least twenty survey participants reporting practices implemented with the use of these assistance programs.

A total of only 1,244 of 8,682 acres (14\%) of timber stand improvement (TSI) application occurred with the assistance of cost-share dollars. Thirty-four (or 21\%) respondents that reported application used cost-share programs to do so (Table 6). The most acreage in which this practice was applied through the assistance of cost-share programs (596 total acres) was reported between 2000 and 2002 (Figure 2). This was also the time during which TSI was performed with or without the aid of cost-share programs on a total of over 3,000 acres.

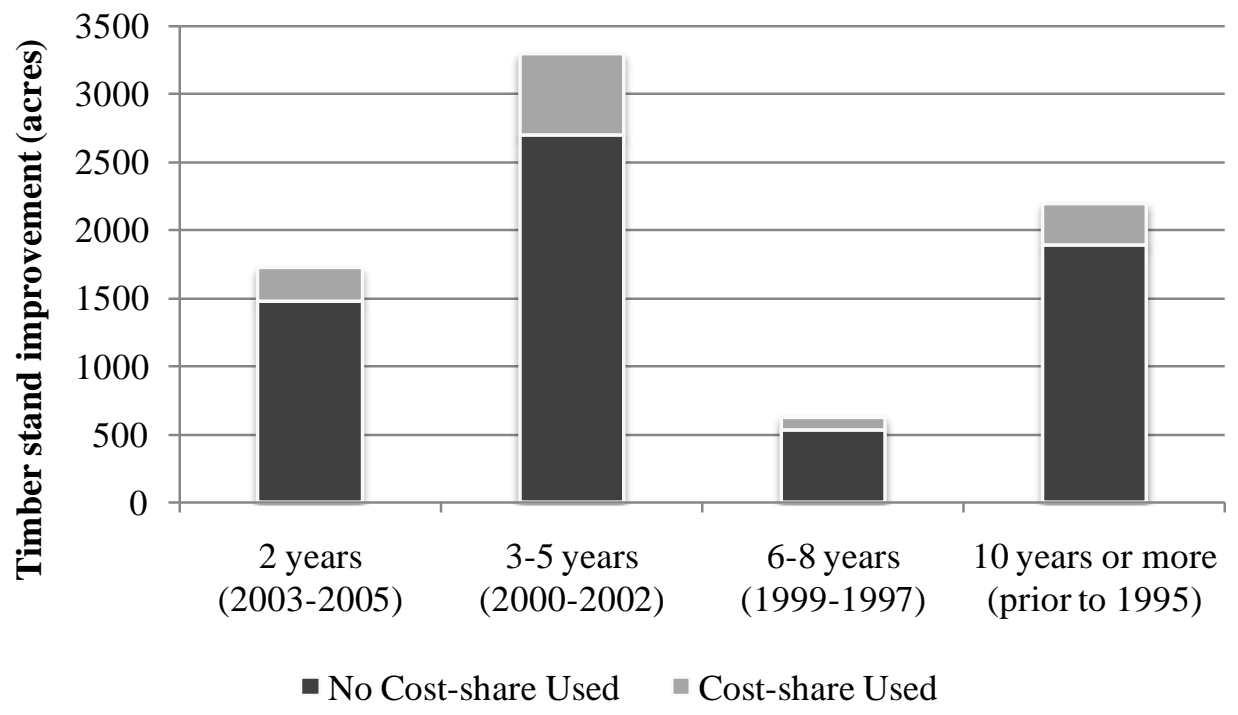

Figure 2. Use of cost-share programs to implement timber stand improvement (TSI). The total extent of practice application is shown by time period of application and whether or not cost-share funds were used. 
Of the respondents that reported applying grapevine control on their properties, twentynine (or 22\%) also reported using cost-share programs for this practice implementation (Table 6). Just over one-quarter of the total acres (1,370 of 5,095 acres) on which this practice was applied was reported to have been completed using cost-share assistance. The total extent in which grapevine control had been applied with the use of cost-share funding was greatest for those that reported implementation occurring 10 or more years ago (Figure 3). During this time, 846 acres had been treated for grapevine control with these assistance programs. The greatest application of grapevine control, totaling to almost 2,200 acres, was reported between 2003 and 2005. Only 90 acres were treated in conjunction with cost-share dollars during this two-year period.

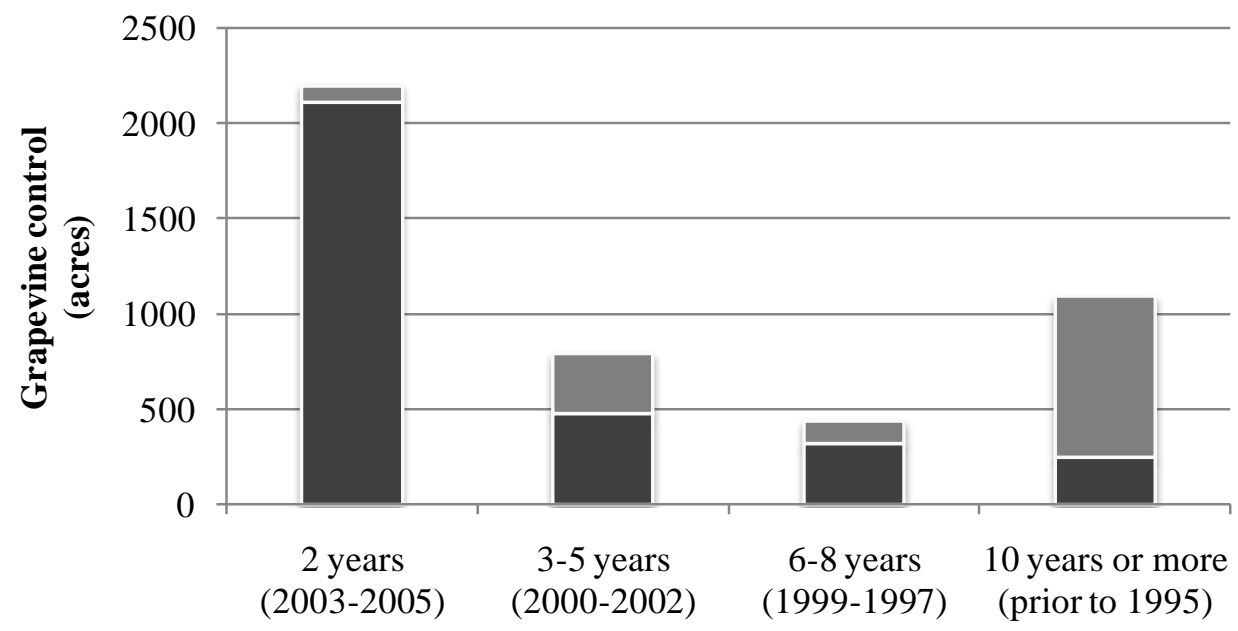

- No Cost-share Used n Cost-share Used

Figure 3. Use of cost-share programs to implement grapevine control. The total extent of practice application is shown by time period of application and whether or not cost-share funds were used. 
Throughout the existence of the FSP, twenty-seven (or 26\%) of the survey respondents that had planted trees reported the involvement of cost-share dollars (Table 6). One-quarter of all acres (210 of 837 acres) planted were completed under cost-share programs. The use of costshare funds for tree planting was applied to the largest extent prior to 1995 (Figure 4). During this period, 124 total acres were planted using funding from these programs. The second highest extent of application with the use of these funds was between 2000 and 2002, during which sixty acres were planted. Between 2003 and 2005, over 300 acres of trees were planted, of which only sixteen were planted with the assistance of cost-share funds.

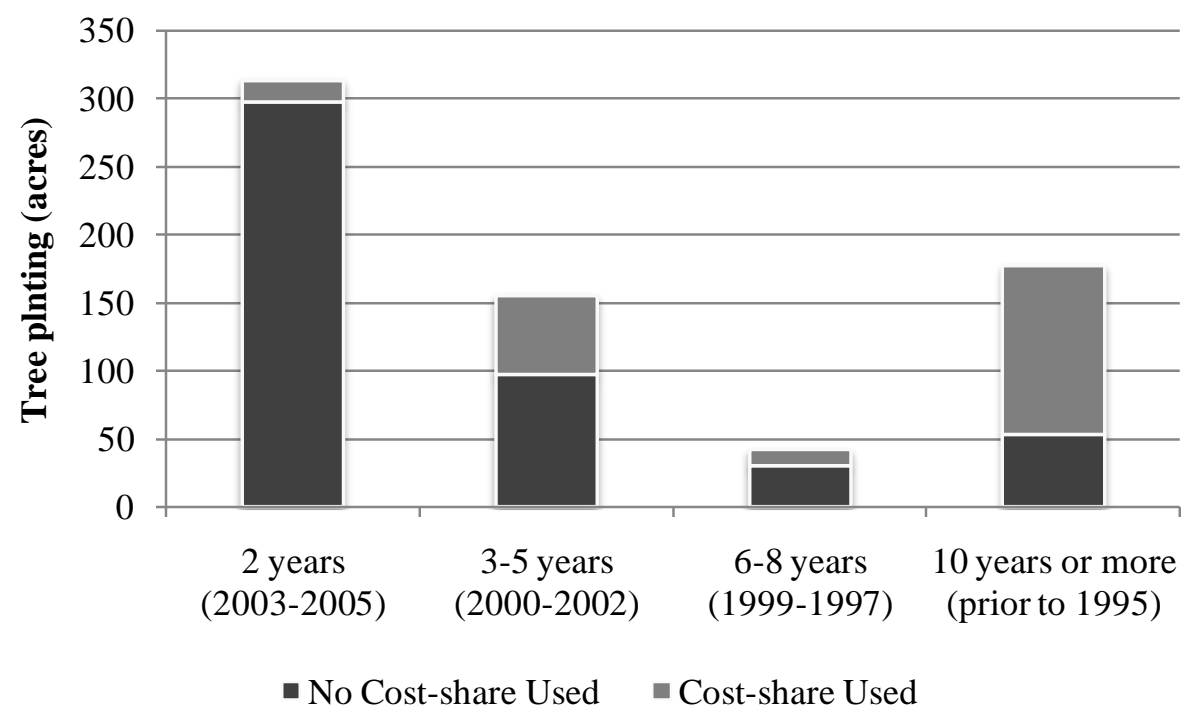

Figure 4. Use of cost-share program for tree planting. The total extent of practice application is shown by time period of application and whether or not cost-share funds were used. 
Of all respondents that reported implementing soil protection and erosion control on their properties, twenty-three (or 15\%) reported the use of cost-share funds to apply such practices (Table 6). Only 15 percent of total acreage (1,010 of 6,795 acres) that was reported for this practice's application was completed with the use of cost-share. The largest extent of application with the help of these assistance programs occurred between 2003 and 2005, in which 522 of 2401 acres received soil protection and erosion control with cost-share dollars (Figure 5). Prior to 1995,276 acres of soil protection was completed with the help of these assistance programs, while another 880 acres were managed for this practice without cost-share programs.

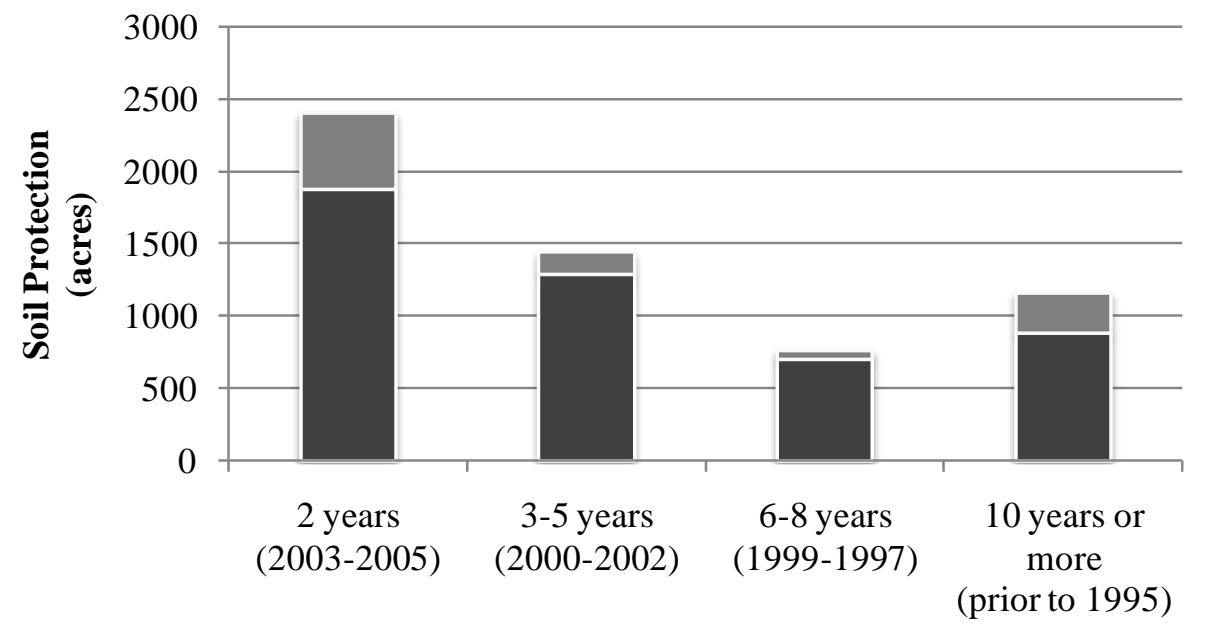

- No Cost-share Used $\quad$ Cost-share Used

Figure 5. Use of cost-share programs for soil protection and erosion control. The total extent of practice implementation is shown by time period of application and whether or not cost-share funds were used. 


\section{Influence of Cost-share Assistance on Extent of Implementation}

Independent t-tests were used to understand whether the use of cost-share programs have an influence on the extent of practice application. This analysis failed to find differences in the average acreage of timber harvesting, grapevine control, wildlife habitat improvement, tree planting, water improvement, soil protection, improvement in appearance, and recreation development between respondents that had and had not utilized cost-share programs. The extent that timber stand improvement (TSI) was significantly different between respondents that used cost-share programs for implementation and those that did not $(\alpha=0.05)$, without assuming equal variance among groups (Table 20). The average extent of application by respondents that did not use cost-share assistance ( $\bar{x}=67$ acres) was significantly higher than those that accessed funding to aid in practice implementation $(\bar{x}=37$ acres). In addition, the amount of forest road construction was significantly different between respondents using cost-share assistance and those that had not $(\alpha=0.05)$. The average mileage of roads built without cost-share dollar was 2.9, while roads built with financial assistance averaged 1.7 miles.

Table 20. Independent t-tests: Extent of practice implementation by the use of cost-share assistance programs.

Std.

\begin{tabular}{llccccc} 
& Cost-share Used & $\mathrm{n}$ & Mean & Deviation & $\mathrm{df}$ & $\mathrm{t}$ \\
\hline TSI & Yes & 34 & 36.59 & 29.38 & 127.88 & $-2.734^{*}$ \\
& No & 98 & 67.55 & 100.42 & & \\
\hline Forest road construction & Yes & 7 & 1.71 & 0.76 & 32.62 & $-2.25^{*}$ \\
& No & 33 & 2.88 & 2.47 & & \\
\hline
\end{tabular}

$* p<0.05$.

Consistency of Responses between Surveys ( $Q 2.1, p g$ 23)

The mail survey of the West Virginia FSP (Jennings, 2003) and the telephone follow-up survey were compared to find inconsistent responses by participants who were the primary respondent to both surveys. In comparing the total number of acres owned and the extent that specific practices were applied, 16 respondents reported that they owned 10 acres or less below the reported acres on which practices were applied. Twenty-seven respondents reported total acreage owned was 11 to 490 acres less than the reported extent of practice application. Focusing on the primary participants of both surveys $(n=191)$, this totals to 22 percent of respondents reporting inconsistently in terms of acres owned or acres of practice application. A 
total of five respondents reported similarly, but also reported that they had increased their property holdings since their enrollment in the WV FSP.

Inconsistencies between the mail survey (Jennings, 2003) and the telephone survey were also found by comparing responses of whether or not a specific practice was implemented to some degree. The majority of respondents that reported wildlife habitat improvement (80\%) and timber harvesting (79\%) application in the earlier study reaffirmed practice implementation in the telephone survey (Table 21). Just over three-quarters of respondents (76\%) consistently reported that grapevine control practices had been applied on their properties, while 14 respondents stated that the practice was not implemented. Less than one half had confirmed application of forest road construction (46\%) and recreational opportunities development (45\%). The practice showing the lowest percent of respondents reporting application in both surveys was water improvement, with only 24 percent consistency between surveys.

Table 21. Responses given by participants that reported practice application in the mail survey (Jennings, 2003) and had been recontacted through the follow-up telephone survey two years later.

\begin{tabular}{lccccc}
\hline & Mail Survey & \multicolumn{4}{c}{ Recontacted } \\
& & \multicolumn{3}{c}{$\begin{array}{c}\text { Did not apply } \\
\text { practice }\end{array}$} \\
\cline { 2 - 6 } \multicolumn{1}{c}{ Practice } & $\mathrm{n}$ & $\mathrm{n}$ & $\%$ & $\mathrm{n}$ & $\%$ \\
\cline { 2 - 6 } Wildlife Habitat Improvement & 60 & 48 & 80 & 12 & 20 \\
Timber Harvest & 63 & 50 & 79 & 13 & 21 \\
Grapevine Control & 60 & 46 & 77 & 14 & 23 \\
TSI & 74 & 51 & 69 & 23 & 31 \\
Tree Planting & 34 & 23 & 68 & 11 & 32 \\
Improve appearance & 58 & 34 & 59 & 24 & 41 \\
Soil Protection & 57 & 33 & 58 & 24 & 42 \\
Forest Road Construction & 48 & 22 & 46 & 26 & 54 \\
Recreation Development & 64 & 29 & 45 & 35 & 55 \\
Water Improvement & 42 & 10 & 24 & 32 & 76 \\
\hline
\end{tabular}

Note: Percentages are based on the proportion of respondents that confirmed/failed to confirm application of the practices during the telephone survey, when they had reported practice application during mail survey (Jennings, 2003).

Of respondents that reported no practice application in the mail survey (Jennings, 2003), inconsistencies were also found, but not to the degree of those that reported practice implementation (Table 22). Nearly three-quarters or better of respondents that reported no application of forest road construction (81\%), tree planting (77\%), recreational development 
(72\%), timber harvesting (71\%), and water improvement (71\%) in the previous survey confirmed this during the follow-up telephone survey. Although this type of inconsistency represented low numbers of respondents, some applications were reported in the follow-up survey but were not reported in the mail survey. Between 40 and 50 percent of respondents reported these inconsistencies in terms of the application of improvements in appearance (52\%), timber stand improvement (45\%), soil protection (45\%), and wildlife habitat improvement (40\%).

Table 22. Responses given by participants that reported practice no application in the mail survey (Jennings, 2003) and had been recontacted through the follow-up telephone survey two years later.

\begin{tabular}{lccccc}
\hline & $\begin{array}{c}\text { Mail Survey } \\
\text { Did not apply } \\
\text { practice }\end{array}$ & Applied practice & \multicolumn{2}{c}{$\begin{array}{c}\text { Recontacted not apply } \\
\text { practice }\end{array}$} \\
\cline { 2 - 6 } & $\mathrm{n}$ & $\mathrm{n}$ & $\%$ & $\mathrm{n}$ & $\%$ \\
\hline Forest Road Construction & 32 & 6 & 19 & 26 & 81 \\
Tree Planting & 48 & 11 & 23 & 37 & 77 \\
Recreation Development & 25 & 7 & 28 & 18 & 72 \\
Timber Harvest & 38 & 11 & 29 & 27 & 71 \\
Water Improvement & 31 & 9 & 29 & 22 & 71 \\
Grapevine Control & 24 & 8 & 33 & 16 & 67 \\
Wildlife Habitat Improvement & 20 & 8 & 40 & 12 & 60 \\
Soil Protection & 29 & 13 & 45 & 16 & 55 \\
TSI & 20 & 9 & 45 & 11 & 55 \\
Improve appearance & 23 & 12 & 52 & 11 & 48 \\
\hline
\end{tabular}

Note: Percentages are based on the proportion of respondents that confirmed/failed to confirm

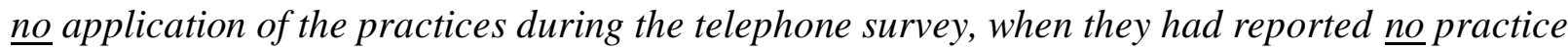
application during mail survey (Jennings, 2003).

There may have been practice application within the two years between the surveys, which would explain inconsistent responses for respondents that reported no practice application in the earlier survey yet had reported application through the telephone survey (Table 23). A substantial proportion of respondents reporting application of timber harvesting (73\%) and improvement in forestland appearance $(67 \%)$ in the telephone survey and reporting no such application in the mail survey stated that the practice application occurred between 2003 and 2005. Fifty percent or more of respondents with the same type of inconsistent applications had applied tree planting, soil protection, and grapevine control during this period as well. Some respondents noted that application of all practices had occurred between 2000 and 2002, ranging 
from 12 to 37 percent of responses. Some of these inconsistent responses cannot be explained by time of application. Between one and three respondents (nine to 37\%) reported that the practice application reported in the telephone survey occurred between 1997 and 1999, and others reported implementation at least 10 years prior to the follow-up survey.

Table 23. Time of application for respondents that reported application in telephone survey, but not in the previous mail survey (Jennings, 2003).

\begin{tabular}{|c|c|c|c|c|c|c|c|c|c|}
\hline \multirow[b]{2}{*}{ Practice } & \multirow[b]{2}{*}{$\mathrm{n}$} & \multicolumn{2}{|c|}{$\begin{array}{l}\text { Past two years }^{\text {a }} \\
(2003-2005)\end{array}$} & \multicolumn{2}{|c|}{$\begin{array}{l}3-5 \text { years ago } \\
(2000-2002)\end{array}$} & \multicolumn{2}{|c|}{$\begin{array}{c}\text { 6-8 years ago }{ }^{b} \\
(1997-1999)\end{array}$} & \multicolumn{2}{|c|}{$\begin{array}{l}10+\text { years ago } \\
\text { (prior to } 1995 \text { ) }\end{array}$} \\
\hline & & $\mathrm{n}$ & $\%$ & $\mathrm{n}$ & $\%$ & $\mathrm{n}$ & $\%$ & $\mathrm{n}$ & $\%$ \\
\hline Timber Harvest & 11 & 8 & 73 & 3 & 27 & & & & \\
\hline Improve appearance & 12 & 8 & 67 & 3 & 25 & & & 1 & 8 \\
\hline Tree Planting & 11 & 6 & 55 & 3 & 27 & 1 & 9 & 1 & 9 \\
\hline Soil Protection & 13 & 7 & 54 & 3 & 23 & 2 & 15 & 1 & 8 \\
\hline Grapevine Control & 8 & 4 & 50 & 1 & 12 & & & 3 & 37 \\
\hline TSI & 9 & 4 & 44 & 3 & 33 & & & 2 & 22 \\
\hline Recreation Development & 7 & 2 & 29 & 1 & 14 & 2 & 29 & 2 & 29 \\
\hline Wildlife Habitat Improvement & 8 & 2 & 25 & 3 & 37 & 3 & 37 & & \\
\hline Water Improvement & 9 & 2 & 22 & 2 & 22 & 3 & 33 & 1 & 11 \\
\hline Forest Road Construction & 6 & 1 & 17 & 2 & 33 & 2 & 33 & & \\
\hline
\end{tabular}

a. Response inconsistencies explained by practice implementation occurring between the mail survey (Jennings, 2003) and recontacted through the telephone follow-up survey

b. Response inconsistencies not explained by time frame of practice implementation. Application occurred prior to the mail survey (Jennings, 2003). 


\section{CHAPTER V}

\section{Discussion}

The success of the Forest Stewardship program in West Virginia can be measured by different attributes associated with participant satisfaction and their reports on the effectiveness of the program. Based on the results from this study, the majority of respondents $(86 \%)$ found that their stewardship plans were useful and many (69\%) referred to it at least once a year (Table 3). Previous examinations of the FSP in various parts of the country have found that landowners benefit from the professional advice, technical assistance, and educational amenities of the program. FSP participants have access to a valuable source of information and technical assistance in helping to understand the concepts of sustainable forest management (Jennings \& McGill, 2005; Baughman \& Updegraff, 2002; Esseks \& Moulton, 2000).

Rather than looking at the open-ended statements and Likert scale ratings of the program by participants to measure the success of the Forest Stewardship Program, researchers began to inquire about the implementation of stewardship plan recommendations on the ground (Egan et al., 2001; Jennings, 2003; Esseks \& Moulton 2000; Baughman \& Updegraff, 2002). This study followed suit by asking participants about the practices they had implemented on their forestland, but also sought to quantify their forest management actions by examining the extent of practice implementation, in terms of acres or miles receiving treatment.

Nationally, $84 \%$ of FSP participants have started to implement some of the recommended forest management practices from their stewardship plans (Esseks \& Moulton, 2000). Based on this subsample of West Virginia FSP participants, this study found that the implementation rates of all surveyed forest management practices were substantially higher than those reported in the program's first evaluation (Egan et al., 2001), yet less than rates found during the ten-year assessment (Jennings \& McGill, 2005). The ten-year assessment of the WV FSP indicated that the most common practices implemented as recommended were wildlife habitat improvement (78\%), timber stand improvement (TSI) (74\%), development of recreational opportunities (71\%), and soil protection (70\%). In comparison, the follow-up survey indicated that recommended implementation was most common for TSI (66\%), soil protection (64\%), improvement in appearance (60\%), and timber harvesting (59\%) (Table 6). 
Very little research has examined the extent that forest management practices have been implemented on FSP-enrolled properties. However, Baughman \& Updegraff (2002) studied this matter in six north central states (IL, IN, IA, MI, MN, and WI). While differences in the designation of forest management practices and their categorization exist with this and the current study, some comparisons can be made (Table 8). They found that timber harvesting revealed the highest mean of application, with an average of 68.2 acres. Higher in application among WV FSP participants, harvesting was reported on an average of 87.4 acres. Although not examined in the north central states, improvement to forestland appearance and the development of recreational opportunities showed the highest average application in this study, averaging 120.4 and 112.3 acres, respectively.

General wildlife habitat improvement averaged 94.4 acres among WV FSP participants applying this practice. Baughman \& Updegraff (2002) classified practices related to wildlife habitat as planting trees/shrubs for wildlife, improving habitat overall or for endangered species, and wetland/pond development and restoration. The overall average applications of these practices were substantially lower in comparison, with the highest average application occurring for improvements to habitat for endangered species $(\bar{x}=34.1$ acres $)$. Timber stand improvement was also applied on average to a larger extent, with FSP participants in the north central states applying this practice on an average of 44.2 acres, while WV FSP participants applied it on an average of 61.6 acres.

While previous research has shown strong relationships between practice recommendation and its respective implementation (Egan et al., 1997; Jennings \& McGill, 2005; Esseks \& Moulton, 2001), only two practices involved in this study supported this evidence. TSI application and the implementation of soil protection were found to have a significant relationship with practice recommendation during the telephone follow-up interview $(p \leq 0.001)$ (Table 7). Based on the extent of practice application, no significant differences were found between respondents who stated the specific practice was recommended and those who stated it was not.

The landownership objectives of the respondents of this study support past assessments of NIPF owners objectives and reasons for ownership (Stoddard, 1942; Barraclough \& Rettie, 1950; Jones et al., 1995; Baughman \& Updegraff, 2002). The participants of this study are not only interested in maintaining and improving the investment value of their land, they are 
concerned with wildlife habitat, soil protection, and water quality (Table 14 and Table 15). Maintaining and improving the appearance of their forestland was also of substantial importance. Generating primary income or providing supplemental income, however, are ranked lowest in importance for these landowners. Baughman \& Updegraff (2002) concluded that FSP participants were most interested in owning land for the aesthetics or general enjoyment of the forest, space, and recreation (2002). The prior evaluation of WV FSP found that the most common objective desired by participants was improving timber production ( $86 \%$ ), followed by creating wildlife habitat (78\%) (Jennings \& McGill, 2005).

NIPF owners are interested in the non-monetary benefits provided from their lands, although they realize the potential to harvest timber if conditions are suitable, such as need for income and mature timber, or if it is recommended in their stewardship plan (Table 12). In support of Egan \& Jones (1993), who found that Pennsylvanian NIPF owners embrace a 'land ethic', the majority of respondents (83\%) from this study reported that the conservation of resources was their reason for implementing forest management on their lands (Table 10).

Because stewardship plans are supposed to incorporate landownership objectives, one way to evaluate this program characteristic is to examine what practices are recommended with respect to the landowner's most important objective (Table 15). For respondents reporting that creating wildlife habitat was important, however, only 41 percent of plans were reported to have wildlife habitat improvement listed as a recommended practice (Table 16). Of respondents that stated 'preventing soil loss' as an important objective, only 29 percent of their plan had soil protection suggested in their stewardship plans. Regardless of the respondents' most important objective, the top three recommended practices in stewardship plans were timber harvesting, grapevine control, and timber stand improvement.

Baughman \& Updegraff (2002) stated that these objectives can also be considered determinants of extent of practice implementation on FSP lands. Respondents who rated 'part of the farm', 'forest products for personal use', 'land investment', and 'income from timber/forest products' as important reasons were inclined to apply more planting for timber, harvesting, TSI, fencing of livestock, planting trees/shrubs for wildlife, soil protection, and road/trail construction than those placing more importance on other objectives (Baughman \& Updegraff, 2002). They also reported that respondents who felt that owning forestland for 'recreation/scenic enjoyment' and as 'part of the home' were important applied the least planting for timber, TSI, soil 
protection, and planting trees/shrubs or grass for riparian buffers (Baughman \& Updegraff, 2002).

With respect to groups of related landownership objectives, some practices were applied to a larger extent of land than others (Table 19). For this study, respondents were categorized based on related landownership objectives as follows:

- Objective Group 1: maintain/improve investment value, generate primary income, and provide supplemental income.

- Objective group 2: create wildlife habitat, develop recreational opportunities, and maintain/improve appearance.

- Objective group 3: prevent soil loss and erosion, and maintain/improve water supply. In support of findings from Baughman \& Updegraff (2002), the average TSI implementation was significantly higher for respondents whose most important objective fell into Objective Group 1 than those in Objective Group 2. Wildlife habitat improvement was applied significantly more by respondents in Objective Group 1 than the other groups. The development of recreational opportunities was revealed to have a significantly higher average for respondents in Objective Group 1 than those in Objective Group 3. These results show that in some cases (such as Objective 1 applying more wildlife habitat improvement than those in Objective Group 2), there are underlying factors influencing their application of practices related to their most important landownership objectives.

Through the establishment and evolution of federal cost-share programs, many studies have shown that they have been essentially underused (Yoho \& James, 1958; Anderson, 1960; Johnson et al., 1999; Kilagore et al., 2002; Jennings, 2005). Contrary to the high percentage of South Carolina's FSP participants that used cost-share dollars to implement their stewardship plans (Melfie et al., 1997), the respondents of this study did not use cost-share on a great number of occasions (Table 8). Nearly two-fifths $(n=103)$ of respondents reported that cost-share assistance was one of their reasons for practicing forest management (Table 12). However, TSI, grapevine control, tree planting, and soil protection revealed the most number of respondents (ranging from 23 to 34 respondents) used cost-share programs to implement management practices (Table 8).

This study found that the extent of application for TSI and forest road construction was significantly different between respondents that had used cost-share programs and those that had 
not (Table 22). Interestingly, respondents that had reported receiving financial assistance applied these practices to a lesser extent (acres and miles) than those that had financial implementation out-of-pocket. Although not compared by finding statistical differences between the users and non-users of these programs, Baughman \& Updegraff (2002) also evaluated the extent of practice application with cost-share dollars. Their results showed that TSI, improving habitat for endangered species, and road/trail construction averaged substantially higher in extent than the average overall implementation with the use of cost-share programs, while the average extent for fencing of riparian areas was substantially lower in this respect. This shows that FSP participants in north central states are more inclined to implement most practices to a greater extent when using financial assistance, while this study of WV FSP participants apply some practices significantly less under cost-share programs.

In support of past studies that have used multiple data collection methods to understand NIPF owners and found inconsistencies in landowner responses (Egan \& Jones, 1993, 1995; Egan et al., 2001), discrepancies were found in the responses reported by individuals that had participated in both the mail questionnaire (Jennings, 2003) and the follow-up telephone survey. Nearly one-quarter $(n=43)$ of these respondents had reported owning less acreage than they reported various forest management practices had been applied, although 16 gave accounts of acreage owned that were within 10 acres of the extent of practice implementation.

Egan \& Jones (1995), who only evaluated responses for timber harvesting, found that 85 percent of recontacted Pennsylvanian NIPF survey participants confirmed harvesting during their forestland ownership. In the first study of the FSP in West Virginia, results showed that about 88 percent $(n=92)$ of participants that were initially surveyed by mail and later took part in a follow-up telephone interview confirmed that they had harvested since their enrollment in the program.

Higher frequencies and percentages of conflicting responses were found in this study. Between 77 and 80 percent of mail survey participants who were recontacted confirmed applying wildlife habitat improvements, harvesting timber, and grapevine control on their forestland as they had reported in the mail survey (Jennings, 2003) (Table 21). However, other practices revealed that as many as 35 respondents who reported practice application in the mail survey failed to confirm implementation during the follow-up telephone survey. Among the highest percentages of inconsistencies were found in water improvement (76\%), the development of 
recreational opportunities (55\%), and forest road construction (54\%). Inconsistencies in responses where the respondent reported practice application in the mail survey and no practice application in the telephone follow-up survey remain unexplained. Some assumptions can be made, such as the respondent did not understand the question or that the practice implementation took place beyond the memory of the study participants, however this survey cannot provide substantial information in this regard.

Inconsistencies in responses were also found if the respondent reported practice implementation in the telephone survey, but had not in the previous mail survey (Jennings, 2003). Because of the time that had passed between the surveys (two years), respondents were asked when the practice had been applied. Some of these inconsistencies were explained by respondents reporting that practice implementation occurred within the two years between the surveys, but other inconsistencies remain unexplained through the examination of time of application. Over three-quarters of respondents failed to confirmed the forest road construction $(n=26)$ or tree planting $(n=37)$ that they had reported implementing on their property during the mail survey (Jennings, 2003) (Table 22). Only one inconsistent response could be explained by the time that forest road construction had been reported to occur (Table 23). Approximately onehalf of respondents who initially said that no improvement in forestland appearance, TSI, or soil protection had been implemented, contradicted these reports during the telephone survey. Between 44 and 67 percent of these respondents that had applied these practices had done so within the two-year period (2003-2005) that followed their participation in the mail survey (Table 23). In fact, this was found to be true for most of the practices, although some practice were reported to be implemented prior to the mail survey (2000-2002). Similar to the inconsistencies found when a respondent reported implementation during the mail survey but not in the telephone follow-up, these responses remain unexplained through this study. 


\section{CHAPTER VI}

\section{Conclusions and Recommendations}

By examining the extent of practice application, as well as the reported implementation of forest management practices, this study provides a thorough description of the management that is occurring on properties enrolled in the West Virginia Forest Stewardship Program, as reported by survey participants. In accordance to these findings, the program has been effective in guiding private forest owners to manage their land for many different ecological and economic purposes. The FSP has been a step forward by making technical assistance, educational opportunities, and financial assistance easier to access due to its consolidation of the most needed and valued portions of federal assistance programs to help private forestland owners. A program that encourages a diversified management of NIPFs, rather than focusing on timber production, has been long over-due.

Practice recommendations were not significant in determining all but two implemented practices. This may be related to changing values and objectives of these landowners, and the need to update stewardship plans to meet their ownership goals. At least in this study, landownership objectives were not clearly evident in the practices that were recommended in stewardship plans, in addition to the implemented practices reported by respondents. It seemed that the stewardship plans were 'carbon copies', or replications, among these participants. However, there are multiple approaches to achieving the objectives that landowners feel are important and without looking at the physical and ecological characteristics of these tracts and the stewardship plans associated with them, only partial inferences can determine if plans are addressing the specific objectives of the landowner.

The use of cost-share programs was found to have little influence on the extent of forest management application, and may not be an effective determinant of the practices implemented by these landowners. Cost-share assistance is based on the federal allocation of funding for support, and as time has passed, these programs have shifted in practices covered under them, the amount of assistance available to private forestland owners, and the natural resource agency administering them. Stability and consistency is the key to program success, as well as increased outreach to NIPF owners. 
Multiple survey methods can be an effective approach to clarifying the management that is occurring on private forestlands. Although conflicting responses were found, a better understanding of the results from the ten-year assessment of the WV FSP was found by distinguishing between consistent and inconsistent responses. Limited funding, time, and other resources to conduct social research can restrict the utilization of multiple data collection methods. This study confirms that discrepancies occur in social surveys. Without a follow-up interview or visit to a sub-sample of properties, the results can be inaccurate. The purpose of social research is to understand social phenomena and to provide information to policy-makers, stakeholders, and the general public. Inaccurate representations can have lasting effects in policy and programs. In addition, it can result in greater loss of resources than would have been used if investment had been directed towards a multiple evaluation approach that is logical to understand the social problem. This study found that there were substantial numbers of respondents reporting practice implementation during the two-year period between the telephone survey and the ten-year assessment by Jennings (2003). In a sense, the prior evaluation was a sort of 'accountability' check for program participants, and may have encouraged these landowners to apply more management on their forestlands.

\section{Recommendations}

Future research on the determination of characteristics that influence the extent of practice implementation would shed light on what is occurring on the ground and help in the improvements of programs that currently exist to assist NIPF owners. More research is needed

to further evaluate management actions through on-site inventories of practices being applied on lands enrolled in the FSP. By continuing to monitor the progress of private forest management, administrating state forestry agencies will be more prepared to provide relevant training to stewardship planwriters that provide the technical assistance side of the program and find ways to approach management trends they find occurring on regional scales. While outreach and educational opportunities are available and publicized to program participants, more exposure should be geared towards non-participants, both NIPF owners and the general public as well, in order to increase FSP enrollment and general knowledge of forest management. 


\section{LITERATURE CITED}

Alderman, L., Mahoney, E. 2005. Above the Smoke: a family album of Pocahontas County fire towers. Published by_Pocahontas Communications Cooperative.

American Association for Public Opinion Research. 2008. Standard Definitions: Final Dispositions of Case Codes and Outcome Rates for Surveys, $5^{\text {th }}$ Edition. Lenexa, Kansas: AAPOR. Accessed on April 13, 2009 from <www.aapor.org/uploads/Standard_Definitions_04_08_Final.pdf>.

American Tree Farm System. 2004. About Us, Tree Farm Today. Accessed on January 21, 2009 from <www.treefarmsystem.org>.

Anderson, W.C. 1960. The small forestland owner and his woodland. USDA Forest Service, Southeastern Forest Experience Station Paper 114. 15 p.

Barraclough, S. and Rettie, J.C. 1950. The ownership of small forestland holding in 23 New England towns. USDA Forest Service, Northeast Forest Experiment Station Paper 34. $32 \mathrm{p}$.

Baughman, M.J. and Updegraff, K. 2002. Landowner Survey of Forest Stewardship Plan Implementation: Final Report to the USFS Forest Service, Northeastern Area State and Private Forestry. University of Minnesota, Department of Forest Resources, St. Paul, MN.

Best, C. and Wayburn, L.A. 2001. America's Private Forests: Status and Stewardship. Island Press, The Pacific Forest Trust, Inc.

Bosworth, D. 2004. Four Threats to the Nation's Forests and Grassland. In speech at the January $16^{\text {th }}$ Idaho Environmental Forum. Access on September 26, 2008 from $<$ http://www.fs.fed.us/news/2004/speeches/01/idaho-four-threats.shtml>.

Birch, T. W., N. P. Kingsley. 1978. Forest-land owners of West Virginia. Resource Bull, NE-58. Broomall, PA: U.S. Dept of Agriculture Forest Service, Northeastern Forest Experiment Station. 76 p.

Birch, Thomas W. 1996. Private forest-land owners of the United States, 1994 Resour. Bull. NE-134. Radnor, PA: U.S. Department of Agriculture, Forest Service, Northeastern Forest Experiment Station. 183 p.

Butler, B., Leatherberry, E. 2004. America's Family Forest Owners. Journal of Forestry 102(7):4-9. 
Butler, B.J. 2008. Family Forest Owners of the United States, 2006. Gen. Tech. Rep. NRS-27. Newton Square, PA: U.S. Department of Agriculture, Forest Service, Northern Research Station. 72 p.

Childs, R.A., 2005. West Virginia's Forests: Growing West Virginia's Future. Bureau of Business and Economic Research, College of Bus. \& Econ., West Virginia University. Morgantown, WV.

Clarkson, R. 1964. Tumult on the Mountains: lumbering in West Virginia, 1770-1920. Published in Parsons, WV by McClain Print. Co.

Cubbage, F.W., O’Laughlin, J., \& Bullock III, C.S. 1993. Forest Resource Policy. Published by John Wiley \& Sons, Inc.

Decoster, L. 1998. The Boom in Forest Owners - A Bust for Forestry? Journal of Forestry 96(5):25-28.

Egan, A.E. 1993. Forest Stewardship: The Relationship between the Articulations and Actions of Pennsylvania's NIPF Owners. PhD. Thesis. Pennsylvania State University.

Egan, A.E., Jones, S.B., Luloff, A.E., \& Finley, J.C. 1995. The Value of Using Multiple Methods: An Illustration Using Survey, Focus Group, and Delphi Techniques. Society and Natural Resources 8:457-465.

Egan, A., and S. Jones. 1995. The reliability of landowner survey responses to questions on forest ownership and harvesting. Northern Journal of Applied Forestry. 12(4):184-186.

Egan, A.E. 1997. From Timber to Forests and People: A View of Nonindustrial Private Forest Research. Northern Journal of Applied Forestry 14(4):189-193.

Egan, A.F., Luloff, A.E. 2000. The exurbanization of America's Forests. Journal of Forestry 98(3):26-30.

Egan, A., Gibson, D., \& Whipkey, R. 2001. Evaluating the Effectiveness of the Forest Stewardship Program in West Virginia. Journal of Forestry 99(3):31-36

English, B.C., Bell, C.D., Wells, G.R. and Roberts, R.K. 1997. Stewardship Incentives in Forestry: Participation Factors in Tennessee. Southern Journal of Applied Forestry 21(1):5-10.

Esseks, J.D. and Moulton, R.J. Evaluating the Forest Stewardship Program Though a National Survey of Participating Forest Land Owners. Northern Illinois University, Social Science Research Institute, Center for Governmental Studies, De Kalb, IL. 111 p.

Fajvan, M.A., Grushecky, S.T., \& Hassler, C.C. 1998. The Effects of Harvesting Practices on West Virginia's Wood Supply. Journal of Forestry 96(5):33-39. 
Gray, J.L. 1978. The Nonindustrial Private Forest Ownership "Problem": A viewpoint. Journal of Forestry 76(8):466-503.

Griffith, D.M., and R.H. Widmann. 2003. Forest statistics for West Virginia: 1989-2000. USDA For. Serv. Res. Bull. NE-157. 119 p.

Hailu, Y.G. 2002. Growth Equilibrium Modeling of Urban Sprawl on Agricultural Lands in West Virginia. M.S. Thesis. Morgantown, WV. 111 p. West Virginia University.

Hicks, R., Jr., 1998. Ecology and Management of Central Hardwood Forests. John Wiley \& Sons, Inc., New York, New York. 412 p.

James, L.M. and Schallau, C.H. 1961. Forest Practices under the Agricultural Conservation Program. Land Economics 37(2):142-149.

Jennings, B. 2003. Implementation of recommended forest stewardship program practice in West Virginia: ten-year assessment. MS Thesis. Morgantown, WV. 68p. West Virginia University.

Jennings, B., Magill, D., McGill, D., and Warren, J. 2003. Patterns offorestland owner participation in the West Virginia Forest Stewardship Program. Conference proceedings, Central Hardwood Forest Conference. USDA Forest Service.

Jennings, B. and McGill, D. 2006. Evaluating the effectiveness of the Forest Stewardship Program in West Virginia: Ten-year assessment. Northern Journal of Applied Forestry 22(4):236-242.

Johnson, R.L., Alig, R., Kline, J., Moulton, R., and Rickenbach, M. 1999. Management of NonIndustrial Private Forest Lands: Survey Results from West Oregon and Washington Owners. Research Contribution 28, Forest Research Laboratory, Oregon State University, Corvallis.

Jones, S.B., Luloff, A.E., and Finley, J.C. 1995. Another look at NIPF's, facing our "myths". Journal of Forestry 93(9): 41-44.

Keniston, R.F. 1962. The Forest Owner-A Person. Journal of Forestry 60(4):249-254.

Kilagore, M.A., Greene, J.L., Jacobson, M.G., Straka, T.J., and Daniels, S.E. 2007. The influence of financial incentive programs in promoting sustainable forestry on the Nation's family forests. Journal of Forestry 105(4):184-191.

Melfie, F.M., Straka, T.J., Marsinko, A.P., and Baumann, J.L. 1997. Landowner Attitudes toward South Carolina's Forest Stewardship Program. Southern Journal of Applied Forestry 21(4):158-163. 
Moulton, R.J., and Hernandez, G.A. 1999. Tree Planting Summary in the United States-1998. Tree Planter's Notes 49(2):23-36.

Natural Resource Conservation Service. 2004. EQIP Fact Sheet. Accessed on January $10^{\text {th }}, 2009$ from <www.nrcs.usda.gov/programs/farmbill/2002/pdf/EQUIPFct.pdf>.

Natural Resource Conservation Service (NRCS. 2004. WHIP Program Description. Accessed on January $10^{\text {th }}, 2009$ from <www.nrcs.usda.gov/programs/farmbill/2002/pdf/WHIPPrDs.pdf>

Nyland, R. 1992. Exploitation and Greed in Eastern Hardwood Forests. Journal of Forestry 90(1):33-37.

Ott, Lyman. 1988. An Introduction to Statistical Methods and Data Analysis, Third Edition. Published by PWS-KENT Publishing Co., Boston, MA.

Ricketts, T.H., Dinerstein, E., Olson, D.M., Louks, C.J. et al. 1999. Terrestrial Ecoregions of North America: a Conservation Assessment. World Wildlife Fund -United States and Canada. Published by Island Press. 485 p.

Rosenberger, R.S., Gebremedhin, T.G., and Hailu, Y. 2002. An Economic Analysis of Urbanization of Agricultural Land in West Virginia. Division of Resource Management, Research Paper 2002-8. West Virginia University. 28 p.

Royer, J. 1979. Conclusions from a Review of 50 Years of Small Woodland Owner Studies. Center for Resource and Environmental Policy Research, Duke University.

Sampson, R.N. and DeCoster, L.A. 1997. Public Programs for Private Forestry. Published by American Forests, Washington, D.C.

Sampson, N., DeCoster, L. 2000. Forest Fragmentation: Implications for Sustainable Private Forests. Journal of Forestry 98(3):4-8.

Sharp, Paul E. 1949. The Tree Farm Movement; Its Origin and Development. Agricultural History 23(1):41-45.

Skok, R.A. and Gregersen, H.M. 1975. Motivating Private Forestry, an Overview. Journal of Forestry 73(4):202-205.

Smith, V. 2007. Second-home Boom A Boon to West Virginia, Resort Areas Attract Well-Heeled Buyers. The Washington Post (AP). Accessed on September 28, 2008 from $<$ http://www.washingtonpost.com/wpdyn/content/article/2007/10/26/AR2007102600959.html>.

Stein, S.M., McRoberts, R.E., Alig, R.J., Nelson, M.D., Theobald, D.M., Eley, M., Dechter, M., and Carr, M. 2005. Forests on the edge: housing development on America's private forests. Gen. Tech. Rep. PNW-GTR-636. Portland, OR: U.S. Department of Agriculture, Forest Service, Pacific Northwest Research Station. 16 p. 
Stoddard Jr, C.H. 1942. Future of Private Forest Land Ownership in the Northern Lake States. Journal of Land \& Public Utility Economics 18(3):267-283.

Stoddard, C.H. 1961. The Small Private Forests in the United States. Resources for the Future, Inc., Washington, D.C.

Tarrant, R.F., Ewing, R.A., and Gedney, D.R. 1978. Forest Survey and the Nonindustrial Private Ownerships. Journal of Forestry 76(8):470-472.

U.S. Census Bureau. 2009. Quick Facts from the U.S. Census Bureau (Hampshire, Jefferson, Berkley, Morgan, Mineral, Hardy, and Grant Counties). Accessed on April 1, 2008 from $<$ http://quickfacts.census.gov>.

USDA Forest Service. 2005. Forest Stewardship Program National Standards and Guidelines, Second Edition. USDA Forest Service, State and Private Forestry, Cooperative Forestry. Accessed on January 29, 2008 from <www.fs.fed.us/spf/coop/programs/loa/fsp.shtml>.

USDA Forest Service. 2008. Forest Land Enhancement Program. Accessed on March 3, 2009 from <http://www.fs.fed.us/spf/coop/programs/loa/flep.shtml>.

Wear, D.N., Liu, R., Foreman, J.M., Sheffield, R.M. 1999. The effects of population growth on timber management and inventories in Virginia. Forest Ecology and Management 118:107-115.

West Virginia Division of Natural Resources, 2003. Ecological Communities. Accessed on September 26, 2008 from < http://www.wvdnr.gov/Wildlife/Ecolog.shtm>.

West Virginia Forestry Association, 1997. West Virginia Forestry Facts. Accessed on September 22, 2008 from <http://www.caf.wvu.edu/westvaco/facts.htm>.

Whipkey, R. 2001. In interview with Dave McGill and Dan Magill. Unpublished.

Wicker, G. 2002. Chapter 9: Motivation for private forest landowners. In: Wear D.N. \& Gries, J.G. 2002. Southern forest resource assessment. Gen. Tech. Report SRS-53. Asheville, N.C., USDA Forest Service, Southern Research Station. 635 p.

Yoho, J.F., and James, L.M. 1958. Influence of some public assistance programs on forest landowners in northern Michigan. Land Economics 34(4): 357-364.

Zivnuska, J. 1978. Two Studies of Nonindustrial Forestlands-A Critical Review. Journal of Forestry 76(8):467-469. 


\section{APPENDICES}

\section{Appendix A: Definitions of Forest Management Practices}

\section{Definitions of forestry terms: The Dictionary of Forestry, John A. Helms (Society of American Foresters)}

Timber - forest crops and stands containing timber. Wood, other than fuelwood, potentially usable for timber

Harvesting - the felling, skidding, on-site processing, and logging of trees or logs onto trucks; synonym logging

Stand improvement - an intermediate treatment made to improve the composition, structure, condition, health, and growth of even or uneven-aged stands.

Grapevine control - control of the vines on the forestlands which are generally considered as weeds (unwanted plants).

Wildlife habitat improvement - practical application of scientific and technical principals to wildlife populations and habitats so as to maintain or manipulate such populations (particularly mammals, birds and fish), essentially for recreational or scientific purposes.

Forest road construction - construction of different types of roads (out-sloped, in- sloped, drain dips etc.) on the property especially while adopting special forestry practices like timber harvesting, providing openings for recreation etc.

Tree planting - Planting of young seedlings of tree species, one of the components of silvicultural practices.

Water improvement - The act of improving quality of water before or after implementing certain practices on the forestland.

Soil protection - protecting the soils from being eroded or losing their quality due to several environmental (natural) or human activities.

Improvement in appearance - The act or process of improving outward aspects (here, aspects of the forest).

Recreation - an activity pursued during leisure time and by free choice that provides its own satisfaction. 


\section{Appendix B: Pre-survey Mailing Materials}

\section{(1) Pre-survey Postcard}

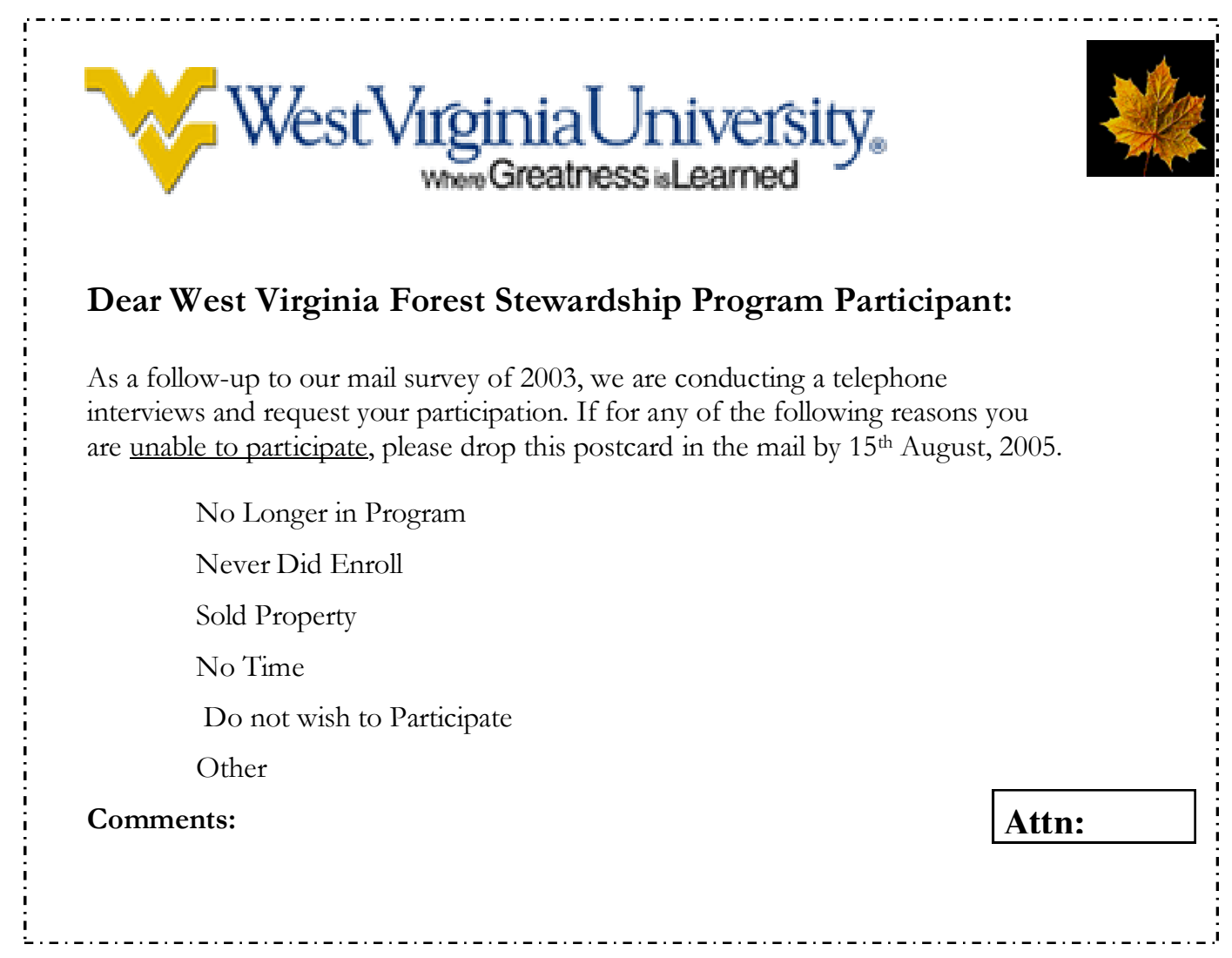




\title{
(2) Pre-Survey Summary of Previous Study (Jennings, 2003)
}

\section{Summary report of the mail survey conducted in 2002 of the Forest Stewardship Program participants in West Virginia.}

\author{
By Brian M. Jennings, David W. McGill and Dheeraj Nelli.
}

\section{Survey Methods}

In 2003, we conducted a survey to assess how many practices listed in West Virginia Forest Stewardship plans have been implemented during the initial ten years of the Forest Stewardship Program (FSP) in West Virginia. The study objectives were to identify the demographics, satisfaction levels of all aspects of the program, motivation behind enrollment, implementation of recommended practices, and participation in other natural resource assistance programs.

At the time of our survey, 3,656 properties had received a management plan under the FSP and were listed in the WV FSP database as having been enrolled within the first 10 years of the program. The survey included a pre-questionnaire announcement postcard, first questionnaire, reminder postcard, and second questionnaire. Stamped return envelopes were sent with the questionnaires to make it easier for program participants to respond to the survey.

\section{$\underline{\text { Results }}$}

We received a high response rate from participant of the WV FSP; sixty-three percent of the questionnaires we sent out were filled out and returned. The summary statistics showed that the average FSP landowner age was 62 years and owns 209 acres with 189 acres enrolled in the program.

\section{Management objectives, recommended practices, and activities}

Of the seven objectives listed in the questionnaire, the top three most important objectives were

-Improvement of timber production,

-Creation of wildlife habitat and

-Prevent of soil loss and erosion.

The three most frequently recommended practices were:

-Stand improvement

-Wildlife habitat improvement

-Timber harvesting

Practices that have been implemented differed slightly in numbers with those recommended in the Stewardship plans. While timber production was recommended as a practice, it was not among the top three implemented practices. The three most frequently implemented practices were:

-Wildlife habitat improvement

-Stand improvement

-Recreation

These practices were followed by soil protection, improving appearance, grapevine control, forest road construction, and timber harvesting and water resources improvement.

The analysis showed that the FSP participants were more likely to implement a recommended forestry practice if it had been recommended in their plan and landowners who use their plan as a reference guide 
tended to implement practices at a higher level. Participation in other private landowner assistance programs was also related to increased implementation of forestry practices.

\section{Landowner assistance}

The majority of the plans were written by private consultants, followed by state service foresters. Landowner objectives were correlated to recommended practices and suggest that plan writers are tailoring the stewardship plans to the objectives of the individual landowner.

Other programs in which West Virginia Forest Stewardship Program (WV FSP) landowners have enrolled in are the West Virginia Managed Timberland Program (WV MTP), Stewardship Incentive Program (SIP), Tree Farm Program, Forest Incentive Program (FIP), Environmental Quality Improvement Program (EQUIP), and Wildlife Habitat Improvement Program (WHIP).

\section{Forest Stewardship Program}

The primary reason for enrollment in the Forest Stewardship Program was landowner's interest in forest management. Satisfaction levels were high for the overall program, the plan author, and the plan itself although some responses indicated otherwise. The bulk of program participants value the program for the usefulness of the plan, its professional assistance and advice, and its educational aspects.

Some survey respondents indicated that there are not enough follow up by plan writers or program sponsors and that there is insufficient cost sharing assistance offered. According to the respondents, landowner education is the best way to promote forest management. Government cost sharing and tax incentives also ranked high as a method to promote forest management among the participants.

\section{More details of this study can be found in:}

Jennings, B.M. 2003. Implementation of Recommended Forest Stewardship Program Practices in West Virginia: Ten-Year Assessment. Master's Thesis. West Virginia University, Morgantown, West Virginia. $60 \mathrm{p}$.

Other related online publications:

http://ahc.caf.wvu.edu/Research/14chc/JenningsGTR316.pdf

http://ahc.caf.wvu.edu/Research/14chc/MagillGTR316.pdf 


\section{Appendix C: Survey Instrument}

\section{FOREST STEWARDSHIP PROGRAM}

\section{Telephone Survey}

1.a. Name of the landowner: (Available on data entry page)

1.b.Telephone number:

1.c.County: 1.d.Date and Time: 105

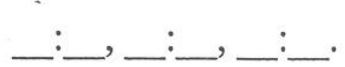

\section{[READ]}

Hello! My name is and I'm calling from West Virginia University. About two years ago your household participated in a mail survey that asked you some questions about your experience with the Forest Stewardship Program. We are now conducting a follow-up to better understand the kinds of forestry activities that you might have carried out on your property during past years. We really appreciate your cooperation and your responses will be kept entirely confidential. You do not need to answer a question if you choose not to do so.

If respondent has any questions about the survey, prior to or after the survey, which cannot be answered, tell her/him to contact Dr. David W. McGill, Forest Resources Extension Specilaist at (304)-293-2941 extn.2474 (or) email at dmcgill@wvu.edu .

2. We are aware that it has been some time since you filled out the mail survey. Was it you or someone else who filled out the mail questionnaire? It was: "me," "not me," "don't remember." [NOTE: It is possible that a forester filled out the survey.]

2.a. IF “IT WAS ME” to Q.2., - SKIP TO QUESTION\#3.

2.b. IF «NOT ME" to Q.2., - Could I speak with the person in your household who filled it out or who is most involved in decisions about managing your woodlands? If available? HELLO [read: "I'm calling from WVU...," then TO QUESTION \#3.] If unavailable, Can I call back at a better time?

2.c. IF THEY SAY "DO NOT REMEMBER" to Q.2., - Could I speak with the person in your household who is most involved in decisions about managing your woodlands? Would you be willing to take time to talk with me about your Stewardship plan? Can I call back at a better time? GO TO QUESTION\#3. 
[READ] WITHIN THE PAST MONTH WE MAILED A LETTER TO ASK YOU TO REVIEW YOUR FOREST STEWARDSHIP PLAN WITH US. WE WOULD LIKE TO ASK YOU SOME QUESTIONS ABOUT YOUR PLAN.

3. Do you consider the Forest Stewardship plan a useful tool to help you implement forestry activities on your property?

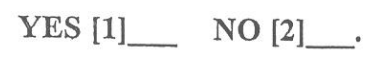

3.a. If YES, would you say you refer to your plan more than once a month, once a month, a couple of times a year, about once a year, once every couple of years, or less frequently?

A. More than once a month

B. Once a month

C. Couple times a year

D. Once a year

E. Once every couple of years, or less

3.b. If NO, tell me whether or not any of the following reasons is true for you? (Read each item, check all that apply:

if true or reason applies $=[1]$, not true $=[2]$.)

A. The recommendations do not address your objectives.

B. The recommendations are too vague to be useful.

C. You're not sure how to carry out the recommendations

D. You don't have time to carry out recommendations

E. The plan is missing or lost.

F. You don't need a plan to manage your forestland..

G. Other reasons:

$\therefore$ 
4. Many landowners have multiple objectives or uses for their land. Please tell us how important each of the following land ownership objectives is for you?

4.a. Read each item on the list below one at a time and then ASK whether it is:

[1] A very important objective or use,

[2] A somewhat important objective,

[3] A somewhat unimportant use or objective,

[4] Not at all important.
A. Maintain and improve investment value
B. Generate primary income
C. Provide supplemental income
D. Create wildlife habitat
E. Maintain and improve appearance
F. Provide for recreation
G. Maintain and improve water quality
H. Prevent soil loss and erosion
I. Are there others: (PLEASE NOTE)

4.b. I'm going to repeat the "very important" uses or objectives that you just identified to me. I'm going to ask you to tell me which one is the single most important to you. What would say is the most important? And then the next?

1. Most important ; 2.next most important 3. Other:

5. How did you acquire your property? Was it acquired through inheritance, purchased, part inheritance and part purchased, or something else?
A. Inheritance
B. Purchased.
C. Both inheritance and purchased
D. Other (probe): 
6.

I'm going to read a list of common forestry practices, and for each practice please tell me if it was a recommended forest practice in your own management plan. [Read for each practice] Was it:

[1] Recommended in the plan,

[2] Not recommended,

[3] You don't know, or cannot recall if it was in your plan.

A. TIMBER HARVEST

B. STAND IMPROVEMENT

C. GRAPEVINE CONTROL

D. WILDLIFE HABITAT IMPROVEMENT

E. FOREST ROAD CONSTRUCTION

F. TREE PLANTING

G. WATER IMPROVEMENT

H. SOIL PROTECTION

I. IMPROVEMENT IN APPEARANCE

J. RECREATIONAL OPPORTUNITIES

K. OTHER FORESTRY PRACTICES: 
7. We need your help to find out about some common Forestry Practices that might have been used or may still be carried out on your property. It will only take a few minutes longer to look at these different forest management practices that you might have used.

\section{A. TIMBER HARVESTING}

A.1. Have you harvested timber?

YES___ (If Yes, go to Q. A.3. below)
NO___ (If No, go to next Q. A.2. )

A.2. (If No) Have any of the following challenges prevented or hindered you from carrying out this forestry practice? (Check all that apply)

1. Costs too much

2. Takes too much time

3. Forest conditions not suitable (e.g. no timber left...)

4. Other challenges:

A.3. (If Yes) How many acres did you harvest?

ACRES, approximate.

A.3.a. How long ago did you harvest timber? Was it within the past 2 years, during the past 5 years, within the past 8 years, or 10 or more years ago. 1. Past 2 years 2. Past 3-5 years 3. Past 6-8 years 4. 10 or more years.

A.3.b Have you harvested more than once in the past 10 years? $1=Y E S$., $2=N O$. A.3.b.1.Please tell how may total acres were harvested?

ACREAS 
A.4. What was your purpose for the harvest? (Check all that apply; $1=Y E S, 2=N O$ )
A. INCOME
B. MATURE OR OVER MATURE TIMBER
C. RECOMMENDED IN THE FOREST STEWARDSHIP PLAN
D. DISEASED OR DAMAGE TREES
E. INSECT INFESTATION
F. CONVERSION - PASTURE / PLANTATION
G. OTHER: (e.g. MINING, SALVAGE, ADJACENT LAND SOLD).

A.5. Was a forester involved?

$$
\text { YES[1] NO[2] }
$$

\section{B. STAND IMPROVEMENT}

B.1. Has there been stand improvement?

YES__ (If Yes, go to Q. B.3. below)

NO__ (If No, go to next Q. B.2.)

B.2. (If No) Have any of the following challenges prevented or hindered you from carrying out this forestry practice? (Check all that apply)

1. Costs too much

2. Takes too much time

3. Forest conditions not suitable (e.g. stand too young ...)

4. Other challenges:

B.3. (If Yes) How many acres was stand improvement applied to? ACRES, approximate.

B.3.a. How long ago was stand improvement applied? Was it within the past

2 years, during the past 5 years, within the past 8 years, or 10 or more years. (if repeated application during 10 years, report all responses) 
1. Past 2 years 2. Past 3-5 years 3. Past 6-8 years 4. 10 or more years.

B.4. Was this activity funded under cost-share program?

YES [1] NO [2]

B.4.a.. If YES, What was the cost share program?

B.5. Were any thinning activities carried out? YES [1] NO [2]

\section{C. GRAPEVINE CONTROL}

C.1. Has there been grapevine control?

YES__ (If Yes, go to Q. C.1.a. below)

NO___ (If No, go to next Q. C.1.a. below)

C.1.a. It is usually advised to have a vegetation inventory to determine the extent of the grape vine problem. Was an inventory conducted on your property?

YES [1] If YES, go to C.3. NO [2] If NO, to C.2., next.

C.2. (ONLY IF NO TO C.1.) Have any of the following challenges prevented or hindered you from carrying out this forestry practice? (Check all that apply)

1. Costs too much

2. Takes too much time

3. Forest conditions not suitable (e.g. no grape vines...)

4. Other challenges:

C.3. (IF YES TO C.1. ABOVE) How many acres was grapevine control applied to? ACRES, approximate.

C.3.a. Did you adopt physical methods (e.g., cutting) or chemical methods for controlling grapevine?

Physical $=[1]$ Chemical $=[2]$ Both physical and chemical=[3] None? $=[4]$. 
C.3.b. How long ago was grapevine control applied? Was it within the past

2 years, during the past 5 years, within the past 8 years, or 10 or more years.

(if repreated application during 10 years, report all responses)

1. Past 2 years 2. Past 3-5 years 3. Past 6-8 years 4. 10 or more years.

C.4. Was this activity funded under cost-share program? YES [1] NO [2]

If YES, What was the cost share program?

\section{D. WILDLIFE HABITAT IMPROVEMENT}

D.1. Has there been wildlife habitate improvement?

YES___ (If Yes, go to Q. D.3. below)
NO___ (If No, go to next Q. D.2.)

D.2. (If No) Have any of the following challenges prevented or hindered you from carrying out this forestry practice? (Check all that apply)

1. Costs too much

2. Takes too much time

3. Forest conditions not suitable (e.g. loss of birds, fish, mammals ...)

4. Other challenges:

D.3. On how many acres was wildlife habitat improvement applied?

ACRES

D.3.a. How long ago was wildlife habitate improvement undertaken?

Was it within the past 2 years, during the past 5 years, within the past 8 years, or 10 or more years.

1. Past 2 years 2. Past 3-5 years 3. Past 6-8 years 4.10 or more years. 
D.4. Was this activity funded under cost-share program?

YES [1] NO [2]

D.4.a. If YES, What was the cost share program?

D.4.b.. Are you a member of WHIP ; that is "Wildlife Habitat Incentives Program"? YES [1] NO [2]

\section{E. FOREST ROAD CONSTRUCTION}

E.1. Has there been forest road construction (e.g., drain dips, in or out-sloped roads)?

YES___ (If Yes, go to Q. 3. below)

NO___ (If No, go to next Q.2.)

E.2. (If No) Have any of the following challenges prevented or hindered you from carrying out this forestry practice? (Check all that apply)

1. Costs too much

2. Takes too much time

3. Forest conditions not suitable (e.g. no roadway access...)

4. Other challenges:

E.3. How many miles of roadway construction have been built? MILES

E.3.a. How long ago was roadway development or improvement undertaken?

Was it within the past 2 years, during the past 5 years, within the past 8 years, or 10 or more years. J5

1. Past 2 years 2. Past 3-5 years 3. Past 6-8 years 4.10 or more years.

E.3.b. What roadwork was built? (IF $\mathrm{DONE}=1$, NOT $\mathrm{DONE}=2$ )

A. OUTSLOPED OR CROWNED ROADS 
B. DRAIN DIPS

C. INSLOPED ROADS WITH DITCHES AND CROSSDRAINS.

D. OTHER:

E.3.c. Was this activity funded under a cost-share program?

YES [1] NO [2]

E.3.c.1. If YES, What was the cost share program?

\section{F. TREE PLANTING}

F.1. Has there been any planting of young seedlings or other planting activities?

YES__ (If Yes, go to Q. 3. below)

NO__ (If No, go to next Q. 2.)

F.2. (If No) Have any of the following challenges prevented or hindered you

from carrying out this forestry practice? (Check all that apply)

1. Costs too much

2. Takes too much time

3. Forest conditions not suitable (e.g. stand too young, no new species)

4. Other challenges:

F.3. (IF YES) How many acres of tree planting has been done?

ACRES

E.3.a. How long ago was this activity undertaken?

Was it within the past 2 years, during the past 5 years, within the past 8 years, or 10 or more years.

1. Past 2 years $\quad$ 2. Past 3-5 years 3 . Past 6-8 years 4 . 10 or more years.

F.4. Was this activity funded under cost-share program?

YES [1] NO [2]

F.4.a. If YES, What was the cost share program? 


\section{G. WATER IMPROVEMENT}

G.1. Has there been activity to improve the quality of water on the forestland?

YES___ (If Yes, go to Q. G.3. below)

NO__ (If No, go to next Q. G.2.)

G.2. (If No) Have any of the following challenges prevented or hindered you from carrying out this forestry practice? (Check all that apply)

1. Costs too much

2. Takes too much time

3. Forest conditions not suitable (e.g. water quality is uncontrollable ...)

4. Other challenges: (mining, livestock, etc.)

G.3. (If YES) What amount of acreage has been involved in water improvement? ACRES

G.3.a. How long ago was this activity undertaken?

Was it within the past 2 years, during the past 5 years, within the past 8 years,

or 10 or more years.

1. Past 2 years 2. Past 3-5 years 3. Past 6-8 years 4. 10 or more years.

G.4. Was this activity funded under cost-share program?

YES [1] NO [2]

G.4.a. If YES, What was the cost share program?

\section{H. SOIL PROTECTION}

H.1. Has there been protection of soils from being eroded or losing their quality? 


YES___ (If Yes, go to Q. H.3. below)
NO___ (If No, go to next Q. H.2. )

H.2. (If No) Have any of the following challenges prevented or hindered you from carrying out this forestry practice? (Check all that apply)

1. Costs too much

2. Takes too much time

3. Forest conditions not suitable (e.g. erosion and human activities...)

4. Other challenges:

H.3. (If YES) What area has been treated for soil protection?

ACRES

H.3.a. How long ago was this activity undertaken?

Was it within the past 2 years, during the past 5 years, within the past 8 years, or 10 or more years.

1. Past 2 years 2. Past 3-5 years 3. Past 6-8 years 4. 10 or more years.

H.4. Was this activity funded under cost-share program?

YES [1] NO [2]

H.4.a .If YES, What was the cost share program?

\section{I. IMPROVEMENT IN APPEARANCE}

I.1.Has there been activity to improve the outward aspects or appearance of the forest?
YES (If Yes, go to Q. I.3. below)
NO__ (If No, go to next Q. I.2. ) 
I.2. (If No) Have any of the following challenges prevented or hindered you from carrying out this forestry practice? (Check all that apply)

1. Costs too much

2. Takes too much time

3. Forest conditions not suitable

4. Other challenges:

I.3. (If YES) Estimate the area under improvement? ACRES

H.3.a. How long ago was this activity undertaken?

Was it within the past 2 years, during the past 5 years, within the past 8 years, or 10 or more years.

1. Past 2 years 2. Past 3-5 years 3. Past 6-8 years 4.10 or more years.

I.4. Was this activity funded under cost-share program?

YES [1] NO [2]

I.4.a. If YES, What was the cost share program?

\section{J. RECREATIONAL OPPORTUNITIES}

J.1. Has there been activity to develop or improve recreational sites of the forestland? YES____ (If Yes, go to Q. J.3. below)
NO___ (If No, go to next Q. J.2. )

J.2. (If No) Have any of the following challenges prevented or hindered you from carrying out this forestry practice? (Check all that apply)

1. Costs too much 
2. Takes too much time

3. Forest conditions not suitable

4. Other challenges:

J.3. (If YES) What is the approximate area setup to promote recreation opportunities? ACRES

J.3.a. How long ago was this activity undertaken?

Was it within the past 2 years, during the past 5 years, within the past 8 years, or 10 or more years.

1. Past 2 years 2. Past 3-5 years 3. Past 6-8 years 4. 10 or more years.

J.4. Was this activity funded under cost-share program?

YES [1] NO [2]

I. 4.a. If YES, What was the cost share program?

J.5. Recreationally, is your forestland property open to the general public or for your own use?

$$
\text { PUBLIC }=[1] \quad \text { PERSONAL }=[2] \quad \text { BOTH }=[3] \text { OTHER }=[4]
$$

J.6. What are the different recreational opportunities possible on your forestland?
A. HUNTING
B. FISHING
C. BIKING
D. HIKING
E. SKIING
F. CAMPING
G. ROCK CLIMBING
H.WHITE WATER RAFTING
I. OTHER

J.7. What are the recreational activities you carry out on your forestland property?
A. HUNTING
B. FISHING
C. BIKING
D. HIKING
E. SKIING
F. CAMPING
G. ROCK CLIMBING
H.WHITE WATER RAFTING
I. OTHER 
K. OTHERS - NOTE ACTIVITY:

8. Are any of the following really strong motivating REASONS for implementing management practices on your property? (Check all that apply)
A. TIMBER HARVESTING IS PRIMARY INCOME
B. I NEEDED THE INCOME/ HARVESTING IS ADDITIONAL INCOME
C. CONSERVATION OF RESOURCES
D. COST SHARE PROGRAMS
E. INFLUENCE OF FRIENDS OR NEIGHBORS
F. OTHER:

THANK YOU FOR YOUR TIME AND PARTICIPATION

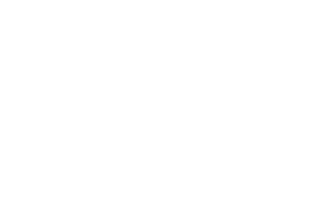

